\title{
Minimum Life Cycle Cost Heat Losses for Shallow Trench Underground Heat Distribution Systems
}

Jin B. Fang

U.S. DEPARTMENT OF COMMERCE

National Bureau of Standards

National Engineering Laboratory

Center for Building Technology

Building Physics Division

Gaithersburg, MD 20899

May 1986

Prepared for:

Tri-Service Building Materials Committee

Headquarters, U.S. Army Corps of Engineers

Washington, DC 20314-1000

U.S. Navy, Naval Facilities Engineering Command

Alexandria, VA 22332-2300

$Q C$

100

Air Force, Air Force Engineering and Services Center all Air Force Base, FL 32403-6001 



\section{MINIMUM LIFE CYCLE COST HEAT}

\section{LOSSES FOR SHALLOW TRENCH}

UNDERGROUND HEAT DISTRIBUTION

SYSTEMS

Jin B. Fang

\section{U.S. DEPARTMENT OF COMMERCE \\ National Bureau of Standards \\ National Engineering Laboratory \\ Center for Building Technology \\ Building Physics Division \\ Gaithersburg, MD 20899}

May 1986

Prepared for:

Tri-Service Building Materials Committee

Headquarters, U.S. Army Corps of Engineers

Washington, DC 20314-1000

U.S. Navy, Naval Facilities Engineering Command

Alexandria, VA 22332-2300

U.S. Air Force, Air Force Engineering and Services Center

Tyndall Air Force Base, FL 32403-6001

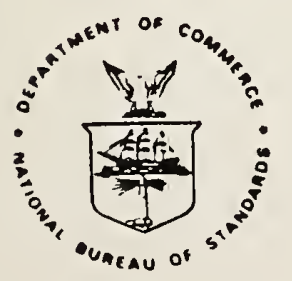

U.S. DEPARTMENT OF COMMERCE, Malcolm Baldrige, Secretary NATIONAL BUREAU OF STANDARDS, Ernest Ambler, Director 

The rates of heat loss from two underground insulated pipes installed in a shallow trench were calculated using a finite element method computer program to solve a two-dimensional steady-state heat conduction problem. The results of pipe heat loss study based on a specified ground temperature condition are summarized for a range of pipe insulation thicknesses, shallow trench sizes, and pipe fluid temperatures. Methods of determining the heat loss associated with the minimum life-cycle cost and the corresponding economic insulation thickness for shallow trench heat distribution systems are presented. Life-cycle costing analysis was performed for two insulated pipes in a concrete trench to determine the cost of construction, annual energy cost associated with pipe heat loss, and yearly operating and maintenance costs. Based on this economic analysis, the least life-cycle cost heat loss and the optimum insulation thickness were determined for specified fluid temperatures in the heat supply and the return lines.

Keywords: finite element method, fuel energy cost, heat loss, life-cycle cost analysis, shallow trench, underground heat distribution system. 
1. Introduction $\ldots \ldots \ldots \ldots \ldots \ldots \ldots \ldots \ldots \ldots \ldots \ldots \ldots \ldots \ldots$

2. System Heat Loss Calculations $\ldots \ldots \ldots \ldots \ldots \ldots \ldots \ldots \ldots$

2.1 The Equations Used for Numerical Solution $\ldots \ldots \ldots \ldots \ldots 1$

2.2 Description of Computer Program $\ldots \ldots \ldots \ldots \ldots \ldots \ldots \ldots$

2.3 Preparation of Input Data $\ldots \ldots \ldots \ldots \ldots \ldots \ldots \ldots \ldots \ldots$

2.4 Sample Calculations $\ldots \ldots \ldots \ldots \ldots \ldots \ldots \ldots \ldots \ldots \ldots$

3. Equivalent Energy Cost $\ldots \ldots \ldots \ldots \ldots \ldots \ldots \ldots \ldots \ldots \ldots \ldots$,

4. Material and Installation Costs $\ldots \ldots \ldots \ldots \ldots \ldots \ldots \ldots \ldots$

5. Maintenance and Repair Costs $\ldots \ldots \ldots \ldots \ldots \ldots \ldots \ldots \ldots, 8$

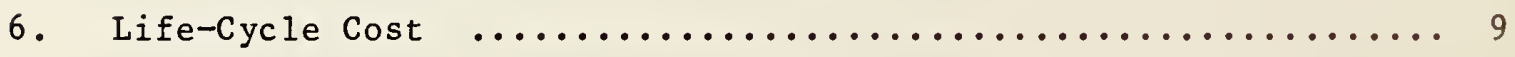

7. Minimum Life-Cycle Heat Loss $\ldots \ldots \ldots \ldots \ldots \ldots \ldots \ldots \ldots \ldots \ldots \ldots \ldots$

8. Conclusions $\ldots \ldots \ldots \ldots \ldots \ldots \ldots \ldots \ldots \ldots \ldots \ldots \ldots \ldots \ldots \ldots, 10$

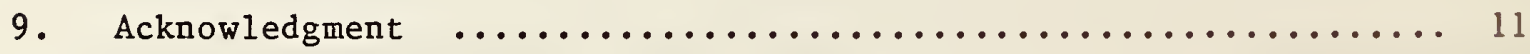

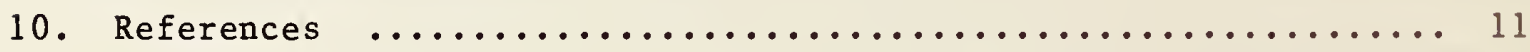

Appendix A. The Input Data Files and the Outputs from the Computer Program on Sample Calculations ........ 23

Appendix B. A Listing of the Computer Simulation Program .... 28 
Table 1. Dimensions of Concrete Shallow Trench Systems for Various Thicknesses of Pipe Insulation

Table 2. Calculated Results of Heat Losses from Two $150 \mathrm{~mm}$ (6-in.) Underground Pipes at Water Temperatures of 196 and 99 C (385 and $210 \mathrm{~F})$.

Table 3. Calculated Results of Heat Losses from Two $150 \mathrm{~mm}$ (6-in.) Underground Pipes at Water Temperatures of 171 and 143 C (340 and 290 F).

\section{LIST OF FIGURES}

Figure 1. Concrete Shallow Trench Underground Heat Distribution System

Figure 2. Finite Element Design for the Outer Boundary Earth and Concrete Trench Walls and Cover

Figure 3. Finite Element Design for Air Space Surrounding the Pipes in Concrete Trench

Figure 4. Finite Element Design for the Pipe Insulation and the Outer Surfaces of the Pipes

Figure 5. Material and Installation Costs of Two $150 \mathrm{~mm}$ (6-in). Pipe Shallow Trench Systems as a Function of Pipe Insulation Thickness

Figure 6. Life-Cycle Cost Analysis for a Shallow Trench System

Figure 7. A Plot of the Life-Cycle Cost Versus the Heat Loss from Underground Pipes at 171 and $143 \mathrm{C}$ (340 and $290 \mathrm{~F}$ )

Figure 8. A Plot of the Life-Cycle Cost Versus the Heat Loss from Underground Pipes at 196 and $99 \mathrm{C}$ (385 and 210 F) 



\section{Introduction}

Underground piping systems distribute hot and chilled water or steam through a network of insulated pipes to serve military installations for space heating and cooling, and industrial purposes. These pipe-lines can be directly buried in the ground, installed in a concrete shallow trench, or placed above the ground. Recent studies [1,2] compared the difference in 1 ife cycle costs between direct buried and shallow trench heat distribution systems based on the results of field surveys of existing systems, and estimates of capital cost, maintenance and operating expenses. Based on both studies, it is difficult to draw any conclusions on cost comparison between these two systems, since their findings are discrepant with each other, especially for systems with large diameter pipes. However, continued construction of concrete shallow trench systems as an a lternative to the direct buried conduit systems is anticipated due to their reduced maintenance and repair costs although they are minor components of the life-cycle cost.

Engineering projects involving substantial expenditures require economically sound investment decisions based on choosing the best alternative. Economic analysis plays an important role in virtually every engineering project, and can identify and evaluate the economic outcome of a proposed project. Life cycle costing is a useful tool in which the individual costs are determined for the expected 1 ife of the project, and the total cost is compared with other alternatives. This approach provides the financial justification for selecting the final design and size for a new underground heat distribution system.

It is well known that the heat loss from piping decreases with an increase in insulation thickness, however a point is reached when further reduction in heat loss becomes uneconomical. In this period of high fuel cost, the conservation of energy through the use of optima 1 insulation thickness corresponding to the minimum life cycle cost heat loss has obvious benefits to reduce fue 1 energy and maintenance expenditures in operating the heat distribution system.

This report describes the methodologies and procedures used to estimate the energy cost associated with the pipe heat loss and the minimum life cycle cost heat loss from various underground shallow trench heat distribution systems. It presents cost data for materials and installation for acquisition, and maintenance and repair costs for some selected trench systems. The heat loss data are prepared for various thicknesses of pipe insulation, for different sizes of shallow trench systems, and for a range of pipe fluid temperatures.

\section{System Heat Loss Calculations}

\subsection{The Equations Used for Numerical Solution}

Finite element methods have been developed to a high level of refinement and have made a great impact in structural mechanics. Such methods are also applied to steady and transient heat conduction problems [3-5]. 
The heat loss per unit length from a shallow trench or a loose-fill insulation underground heat distribution system can be calculated using the computer simulation program developed recently by Kusuda [6]. This program applies the finite element method to a steady-state, two-dimensional shallow trench system consisting of a heat supply and a return pipe having different fluid temperatures for the pipe sizes shown in Figure 1 . The program contains a predesigned finite-element mesh with 130 triangular elements and 80 nodal points. Figure 2 shows the triangular element mesh for the outer boundary earth region, and for the concrete trench walls and cover. Figure 3 shows the mesh for the air space between the insulated pipes and the trench walls, and Figure 4 illustrates the mesh for the pipe insulation. Prescribed boundary temperatures include the nodal points around the outer surfaces of the circular pipes (nodes 49 through 64 in Figure 4) and the perimeter of the earth zone (nodes 65 through 80 in Figure 2). The remaining nodal point temperatures are calculated by solving the system of simultaneous equations using the Gaussian elimination method.

The undisturbed earth temperature used as the prescribed temperature boundary conditions, is a function of time and depth below the ground surface and can be determined by the following eqution [7]:

$$
T=T_{a}+T_{b} \exp \left(-y \sqrt{\frac{w}{2 \alpha}}\right) \sin \left[2 \pi(t-3) / 12-y \sqrt{\frac{w}{2 \alpha}}\right]
$$

where $T=$ the monthly average earth temperature, oC (OF)

$$
\begin{aligned}
\mathrm{T}_{\mathrm{a}} & =\text { the annual average earth temperture of the site, } \mathrm{OC}(\mathrm{OF}) \\
\mathrm{T}_{\mathrm{b}} & =\text { the annual amplitude of the monthly average temperature cycle, } \\
\mathrm{y} & { }^{\circ} \mathrm{C}(\mathrm{oF}) \\
\mathrm{w} & =\text { depth from the ground surface, } \mathrm{m}(\mathrm{ft}) \\
\alpha & =\text { thermal diffusivity of the soil, } \mathrm{m}^{2} / \mathrm{h}\left(\mathrm{ft}^{2} / \mathrm{h}\right) \\
\mathrm{t} & =\text { the elapsed time from January, in months }
\end{aligned}
$$

The rate of heat flow by natural convection through the airspace bounded by the trench walls and the outer surfaces of the insulated piping can be approximated by an equivalent heat conduction of the form $[8,9]$ :

$$
Q / A=k_{e}\left(T_{h}-T_{c}\right) / L
$$

where $Q=$ the average heat flow rate, $W(B t u / h)$

$$
\begin{aligned}
& A=\text { the mean cross-sectional area of the enclosed air layer, } \mathbf{m}^{2} \\
& \left(f t^{2}\right) \\
& \mathrm{k}_{\mathrm{e}}=\text { the effective thermal conductivity of the enclosed air layer, } \\
& \mathrm{W} / \mathrm{m} \cdot \mathrm{K}(\mathrm{Btu} / \mathrm{h} \cdot \mathrm{ft} \cdot \mathrm{OF}) \\
& \mathrm{T}_{\mathrm{h}}=\text { the temperature of the hot surface, }{ }^{\circ} \mathrm{C}(\mathrm{OF}) \\
& \mathrm{T}_{\mathrm{f}}=\text { the temperature of the cold surface, }{ }^{\circ} \mathrm{C}\left({ }^{\circ} \mathrm{F}\right) \\
& \mathrm{f}=\text { the thickness of air layer, m ( } \mathrm{ft} \text { ) }
\end{aligned}
$$

An effective thermal conductivity is used to modify the simple conduction solution to account for convection. The effect of radiant exchange between the pipes and trench walls may be negligible due to low emissivity of aluminum jacket surface. The ratio of the effective to the actual thermal conductivity of the enclosed airspace, $\mathrm{k}_{\mathrm{e}} / \mathrm{k}$, is a function of the Rayleigh number based on the characteristic dimension (the thickness) of the air 
layer and on the temperature difference of the hot and cold surfaces [8]. The effective thermal conductivity is also a function of the product of the convective heat transfer coefficient and the characteristic dimension. It is noted that if the natural convection is suppressed and the heat is transferred through the air layer only by heat conduction, the effective to the actual thermal conductivity ratio is unity. No experimental data or correlations are available on natural convection in air confined between a pair of heated pipes and cooler enclosure walls. However, correlations for free convection through plane or cylindrical air layers in enclosures from a hot to a cold surface is the closest configuration available $[8,9]$.

Convective heat transfer between the ground surface in the vicinity of the shallow trench and the ambient air is dependent upon the local climate and surface conditions. The surface resistance to convective transfer may be considered as being contained in an equivalent soil layer. The thickness of this fictitious layer represents the amount by which the earth boundary is extended to account for the effect of the film resistance due to convection, and can be determined by

$$
L_{c}=\frac{k_{G}}{h}
$$

where $L_{c}=$ the thickness of the equivalent soil layer, $m$ ( $\left.f t\right)$

$\mathrm{k}_{\mathrm{G}}=$ the thermal conductivity of the soil, $\mathrm{W} / \mathrm{m} \cdot \mathrm{K}\left(\mathrm{Btu} / \mathrm{h} \cdot \mathrm{ft} \cdot \mathrm{O}_{\mathrm{F}}\right)$

$\mathrm{h}=$ surface heat transfer coefficient, $\mathrm{W} / \mathrm{m}^{2} \cdot \mathrm{K}\left(\mathrm{Btu} / \mathrm{h} \cdot \mathrm{ft} \mathrm{t}^{2} \cdot \mathrm{o}^{\mathrm{F}}\right)$

The heat loss rate per unit length of piping is obtained using the following equation along with the calculated value of average temperature drop across a circular cylindrical shell of pipe insulation layers:

$$
q=\frac{2 \pi k_{I}\left(T_{i}-T_{0}\right)}{\ln \left(r_{0} / r_{i}\right)}
$$

where $q=$ the heat loss rate per unit length of the insulated underground pipe, $W / m(B t u / h \cdot f t)$

$\mathrm{k}_{\mathrm{I}}=$ the thermal conductivity of insulation materials, $\mathrm{W} / \mathrm{m} \cdot \mathrm{K}$ $\left(\mathrm{Btu} / \mathrm{h} \cdot \mathrm{ft} \cdot \mathrm{O}_{\mathrm{F}}\right)$

$r_{0}=$ outside radius of the insulation layer, $m(f t)$

$r_{i}=$ inside radius of the insulation layer, $m$ ( $f t$ )

$\mathrm{T}_{\mathrm{i}}$ and $\mathrm{T}_{0}=$ the surface temperature of the insulation layer at inner and outer radii $r_{i}$ and $r_{0}$, respectively, ${ }^{\circ} \mathrm{C}\left({ }^{\circ} \mathrm{F}\right)$

For an insulated piping system, the surface film resistance between the hot water and the pipe, and the thermal resistance of the pipe wall can generally be ignored in comparison to the thermal resistance of the insulation.

\subsection{Description of the Computer Program}

The computer program, which is written in FORTRAN language, consists of a main program (FEUHDS) and seven subroutines called PIPE2, TGO, TWOPIP, SOILK, TGXX, SOLVP and PIPEHL. Input data are read in by the main program, and subroutines PIPE 2 and TGO. Output is provided by the main, PIPE2, 
TWOPIP, and PIPEHL programs. In addition to handling portions of input data, the main program coordinates and performs most of the calculations. Subroutines PIPE 2 is used to calculate rectangular coordinates for each nodal point based on the shallow trench and piping geometry, while subroutine TGO calculates the average undisturbed earth temperatures at various depths for the month of interest. Subprogram TWOPIP called from the main program determines the rate of heat loss from two insulated buried pipes to the underground. Subroutine soILK provides soil thermal conductivity values for various earth temperatures by linear interpolation of a set of soil thermal conductivity versus temperature data, and TGXX furnishes the external boundary temperatures of the outer earth region surrounding the shallow trench system. Subroutine SOLVP is used to solve system of simultaneous equations by Gauss elimination method, and PIPEHL computes the temperature drops across the pipe insulation layers and the heat loss rates for both underground pipes. A listing of the source code of this computer program is given in Appendix B.

\subsection{Preparation of Input Data}

Two input data files, DATAl and DATA2, are created prior to execution of the computer simulation program FEUHDS. The DATAl file shown in Appendix A.1 contains data for run control parameters, the month of interest, the thermal conductivity and dimensions of the trench walls, convection conditions for the trench enclosed air space, the pipe fluid temperatures, the thermal conductivities and dimensions of the carrier pipes and insulation layers, the thermal properties and dimensions of the earth region surrounding the trench system, and the annual average temperature and amplitude of the monthly temperature cycle for the site involved. The DATA2 file shown in Appendix A.2 consists of data for the finite-elements including the element number, the node numbers for its three vertices, and the surface convection coefficients and ambient temperatures for the sides of each element that experiences convection loss.

Description of Variables:

The computer program requires that the numerical values of all input variables are in engineering units.

MREPT Number of iterations to be performed for soil temperature and moisture effect analysis

ITREN An index, ITREN $=1$ A shallow trench system

$=0$ A loose-fill insulation system

MONTH Month for which the heat loss is to be determined

ICALB An integer, ICALB $=1$ Nodal coordinates will be printed out $=0$ No print-out

KTCT Thermal conductivity of trench walls, (Btu in $/ \mathrm{h} \cdot \mathrm{ft}{ }^{2} \cdot \mathrm{o}^{\mathrm{F}}$ )

TRTK Thickness of the trench wall, (inches)

RASP Equivalent thermal conductivity of air surrounding the underground pipes in the shallow trench, ( $\mathrm{Btu} \cdot \mathrm{in} / \mathrm{h} \cdot \mathrm{ft}^{2} \cdot \mathrm{O}_{\mathrm{F}}$ ) 
T1,T2 Fluid temperatures of pipe numbers 1 and 2, respectively, (OF)

KII Thermal conductivity of pipe insulation materials, (Btu in $/ \mathrm{h} \cdot \mathrm{ft} \mathrm{t}^{2} \mathrm{o} \mathrm{F}$ )

KIG Thermal conductivity of the soil in the vicinity of the shallow trench, (Btu $\cdot$ in $\left./ h \cdot f t^{2} \cdot{ }^{\circ} \mathrm{F}\right)$

PI1,PI2 Outside diameters of pipe numbers 1 and 2, respectively, (inches)

THI1, Thicknesses of the thermal insulation layers for pipe numbers 1 THI 2 and 2 , respectively, (inches)

B1,B2 Depths from ground surface to the centers of pipe numbers 1 and 2 , respectively, ( $f t$ )

S

TG

WW

$\mathrm{HH}$

HY

D

A

B

AO

$\mathrm{BO}$

DIFF

$\mathrm{N}$

$\mathrm{I}, \mathrm{J}, \mathrm{K}$

C

IXCB
Separation distance between the centers of the pipes, ( $f t$ )

Monthly average earth temperature, $\left({ }^{\circ} \mathrm{F}\right)$

Width of the earth region surrounding the shallow trench system, (ft)

Thickness of the equivalent soil layer to account for the surface convective transfer effect, ( $f t$ )

Depth of the earth region underneath the shallow trench system, $(\mathrm{ft})$

Thickness of the trench cover, ( $f t$ )

Total width of the trench system, ( $f t$ )

Height of the trench wa11, ( $f t$ )

Annual average outdoor temperature of the site, (OF)

Annual amplitude of the monthly average temperature cycle of the site, $\left({ }^{O} F\right)$

Thermal diffusivity of the soil in the vicinity of the trench system, $\left(\mathrm{ft}^{2} / \mathrm{h}\right)$

The element number, dimensionless

The node numbers of three vertices of an element

Thermal conductivity of an element, ( $\left.\mathrm{Btu} \cdot \mathrm{in} / \mathrm{h} \cdot \mathrm{ft} \mathrm{t}^{2} \cdot \mathrm{F}\right)$

An index, IXCB $=1$ The element has convection boundary

$=0$ No convection boundary

HIJ,HJK, Convective heat transfer coefficients for sides IJ, JK and KI of HKI 
TIJ,TJK, Ambient temperatures for sides IJ, JK and KI of an element, $\left({ }^{\circ} \mathrm{F}\right)$ TKI

The input format of these aforementioned variables which are stored in data files DATAl and DATA2, are respectively:

(1) DATA1 File

Record No.

1
2
3
4
5
6
7
8
9
10
11
12
13

\begin{tabular}{l} 
Variables \\
\hline MREPT, ITREN \\
MONTH, ICALB \\
KTCT, TRTK \\
KASP \\
T1, T2 \\
KII, KIG \\
PI1, PI2 \\
THI1, THI2 \\
B1, B2 \\
S, TG \\
WW, HH, HY \\
D, A, B \\
A0, BO, DIFF
\end{tabular}

Format

(I5, 1X, I4)

(2I5)

(2F10.4)

(F10.5)

$(2 \mathrm{~F} 10.3)$

(2F10.4)

(2F10.4)

(2F 10.4)

(2F10.4)

(2F10.4)

(3F10.4)

(3F10.4)

(3F10.4)

\section{(2) DATA2 File}

Record No.

1

2

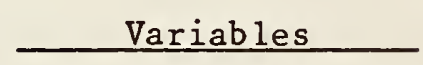

$\mathrm{N}, \mathrm{I}, \mathrm{J}, \mathrm{K}, \mathrm{C}, \mathrm{IXCB}$
Format

$(4 I 5, F 10.4, I 5)$

(Use record No. 2 if $\mathrm{IXCB}=1$ )

HIJ, HJK, HKI, TIJ, TJK, TKI

$(6 \mathrm{~F} 10.4)$

(Repeat record numbers 1 and 2 for a total of 130 elements)

\subsection{Sample Calculations}

Two nomina $1150 \mathrm{~mm}(6-$ inch) stee 1 pipes are laid side by side in a $1.24 \mathrm{~m}$ $(4.08 \mathrm{ft})$ wide by $0.89 \mathrm{~m}(2.92 \mathrm{ft})$ high concrete shallow trench having 152 $\mathrm{mm}$ ( 6 in.) thick trench cover and walls. Figure 1 shows a typical high temperature hot water underground system consisting of a heat supply and a return pipe in a concrete trench with the top cover placed flush with ground level. The hot water pipe temperture is $196^{\circ} \mathrm{C}\left(385^{\circ} \mathrm{F}\right)$ and the return pipe temperature is $99^{\circ} \mathrm{C}\left(210^{\circ} \mathrm{F}\right)$. The centers of both pipes are located $1.30 \mathrm{ft}(0.40 \mathrm{~m})$ beneath the ground surface. The pipes are insulated with an aluminum jacket and $89 \mathrm{~mm}(3.5 \mathrm{in}$ ) thick calcium silicate, allowing $102 \mathrm{~mm}$ ( 4 in.) of separation between surfaces of adjacent pipe insulation. The concrete trench system is surrounded by earth having a therma 1 conductivity of $2.16 \mathrm{~W} / \mathrm{m} \cdot \mathrm{K}\left(15 \mathrm{Btu} \cdot \mathrm{in} / \mathrm{h} \cdot \mathrm{ft} \mathrm{t}^{2} \mathrm{~F}\right)$ and an annual average temperature of $13^{\circ} \mathrm{C}\left(56^{\circ} \mathrm{F}\right)$. The system heat los 8 calculations were carried out on an IBM personal computer. The input data 
files for the sample case and the outputs from the computer program are 1 isted in Appendix A.

In order to maintain some clearances between the insulated pipes and adjoining trench walls and floor as specified in the design guide [10], the concrete trench has different overall dimensions to accommodate various thicknesses of pipe insulation, as listed in Table 1. The effects of the thickness of pipe insulation on the heat loss of the trench system for two sets of pipe temperatures are shown in Tables 2 and 3 . The water temperatures of the heat supply and return lines are $196^{\circ} \mathrm{C}\left(385^{\circ} \mathrm{F}\right)$ and $99^{\circ} \mathrm{C}$ $\left(210^{\circ} \mathrm{F}\right)$, respectively for the heat loss calculations shown in Table 2 , and $171^{\circ} \mathrm{C}\left(340^{\circ} \mathrm{F}\right)$ and $143^{\circ} \mathrm{C}\left(290^{\circ} \mathrm{F}\right)$ in Table 3 . As expected, the results indicate that the total heat loss from the underground piping system decreases with an increase in insulation thickness due to the increased thermal resistance for radial heat conduction. For a given insulation thickness, the rate of heat loss from a single insulated pipe increases with increasing pipe temperature since the convection loss to the trench air is directly proportional to the temperature difference between the outer surface of the pipe and the surrounding air.

\section{Equivalent Energy Cost}

The energy cost per unit length of the shallow trench system is calculated using the computed heat losses from the piping system obtained from the computer program, and the equivalent fuel energy cost adjusted for future escalation in energy prices over the 1 ife of the system. The equation used for calculating the equivalent energy cost (EEC) or the cost of lost energy per annum, is as follows:

$$
\mathrm{EEC}=8760 * \mathrm{Q} * \mathrm{EC} * \mathrm{UPW}^{\star}
$$

where $Q=$ system heat loss rate, which is equal to the sum of the heat loss rates of two pipes, (Btu/h.ft)

$E C=$ equivalent fuel energy cost, ( $\$ / M B t u)$

$=100(\mathrm{FC} / \mathrm{EF})$, in which FC is fuel cost, ( $\$ / \mathrm{MBtu})$, and $\mathrm{EF}$ is plant fue 1 conversion efficiency (percent)

$\mathrm{UPW}^{*}=$ the modified uniform present worth factor adjusted for future escalation in fuel prices.

In this sample case of life-cycle cost calculations, the fue 1 to heat conversion efficiency at the plant is assumed to be $100 \%$, and the price of fuel is at $\$ 5.00$ permillion $B t u$. In reality, the plant fuel conversion efficiency is dependent upon the type of boiler used, and ranges between 50 and 90 percent.

The energy cost is assumed to escalate in accordance with the data on annual inflation rate of natural gas as projected by the U.S. Army Corps of Engineers [1]:

\begin{tabular}{|c|c|c|c|c|}
\hline Type of Fue 1 & $\underline{1985-1990}$ & $\underline{1990-1995}$ & 1995-2000 & $\underline{2000-2009}$ \\
\hline Natural gas & 5.13 & 8.81 & 3.91 & 4.69 \\
\hline Distillate fuel & 6.02 & 5.98 & 3.91 & 4.69 \\
\hline Residual fuel & 6.50 & 6.06 & 3.91 & 4.69 \\
\hline Coal & 1.85 & 3.04 & 3.04 & 3.04 \\
\hline
\end{tabular}


The Modified Uniform Present Worth factor (UPW ${ }^{*}$ ) is calculated based on a $10 \%$ discount rate for a 25 year 1 ife for the underground system, and the escalation rates in natural gas price projected by the U.S. Army Corps of Engineers for the periods covering from 1985 to 2009, using the following equation [11]:

$$
\begin{aligned}
& U P W^{*}=\sum_{j=1}^{N_{1}}\left(\frac{1+e_{1}}{1+d}\right)^{j}+\left(\frac{1+e_{1}}{1+d}\right)^{N_{1}} \sum_{j=1}^{N_{2}}\left(\frac{1+e_{2}}{1+d}\right)^{j} \\
& +\left(\frac{1+e_{1}}{1+d}\right)^{N_{1}}\left(\frac{1+e_{2}}{1+d}\right)^{N_{2}} \sum_{j=1}^{N_{3}}\left(\frac{1+e_{3}}{1+d}\right)^{j} \\
& +\left(\frac{1+e_{1}}{1+d}\right)^{N_{1}}\left(\frac{1+e_{2}}{1+d}\right)^{N_{2}}\left(\frac{1+e_{3}}{1+d}\right)^{N_{3}} \sum_{j=1}^{N_{4}}\left(\frac{1+e_{4}}{1+d}\right)^{j} \\
& \text { where } \sum_{j=1}^{N_{k}}\left(\frac{1+e_{k}}{1+d}\right)^{j}=\left(\frac{1+e_{k}}{d-e_{k}}\right)\left[1-\left(\frac{1+e_{k}}{1+d}\right)^{N_{k}}\right]
\end{aligned}
$$

$N_{k}=$ the length of the period for a given escalation rate in a given period, (year)

$\mathrm{d}=$ the discount rate

$e_{k}=$ the rate of escalation in each of $\mathrm{N}_{k}$ period

The salvage value of a shallow trench heat distribution system after 25 years of service is assumed to be zero. With these economic assumptions, the modified uniform present worth factor, UPW ${ }^{*}$ for the sample case is found to be 15.8 percent.

\section{Material and Installation Costs}

The capital cost including material and installation costs for constructing a shallow trench underground heat distribution systems can be calculated using cost data and the estimate procedures given in references $[1,12-14]$. In order to maintain clearance between the outer surfaces of the pipe insulation and the adjoining trench walls and floor described previously, the trench size varies to accommodate different insulation thicknesses, in accordance with the dimensions listed in Table 1. The costs of materials and installation for constructing concrete shallow trench systems consisting of two $150 \mathrm{~mm}(6-i n$.$) steel pipes with calcium silicate$ insulation encased in aluminum jacket are estimated and shown as a function of insulation thickness in Figure 5. As anticipated, both the material and installation costs $r$ ise with an increase in insulation thickness.

5. Maintenance and Repair Costs

An annual maintenance cost of $\$ 1,000$ per mile for a typical shallow trench system, which was derived from the results of a recent survey of field installations [1], was used for the life-cycle cost analysis. The total present value of these annually recurring costs was calculated by multiplying this maintenance cost by 9.077, the uniform present worth (UPW) 
factor for a $10 \%$ discount rate over a 25 year system 1 ife. This was determined to be $\$ 5.64$ permeter ( $\$ 1.72$ per foot) for the shallow trench system.

Based on the field survey results, the calculations for the present value of the repair costs were carried out with an assumption that these expenditures occur during years 12 through 25 [1]. The present value of the nonannually recurring repair costs was approximately $\$ 0.30$ per meter (\$0.09 per foot), and was neglected compared to the system installation and the routine maintenance costs.

\section{Life-Cycle Cost}

Life cycle cost analysis can be used to determine the total expenses associated with various design alternatives. These expenses would include the cost of acquisition, yearly maintenance and repair cost, and yearly fuel energy cost with the adjustment for future escalation in fuel prices. The total life-cycle cost of an underground heat distribution system can be expressed as follows:

$$
\mathrm{LCC}=\mathrm{MC}+\mathrm{IC}+\mathrm{EEC}+\mathrm{MRC}
$$

where $M C=$ material cost, ( $\$ / f t$ of the underground system)

IC = installation cost, ( $\$ / \mathrm{ft}$ of the system)

EEC = equivalent energy cost including the adjustment for future escalation in energy prices over the life of the system, ( $\$ / \mathrm{ft}$ of the system)

MRC = maintenance and repair costs, ( $\$ / f t$ of the system)

Evaluation of the effect of varying insulation thickness for the underground piping system on the construction and fuel energy costs associated with various insulation thicknesses over the economic life of an underground heat distribution system was performed. Figure 6 shows the effect of pipe insulation thickness on the material and installation costs, equivalent energy cost, and total 1 ife-cycle cost for two $150 \mathrm{~mm}$ (6-in.) pipes installed in a concrete shallow trench based on a $171^{\circ} \mathrm{C}\left(340^{\circ} \mathrm{F}\right)$ supp 1 y and $143^{\circ} \mathrm{C}\left(290^{\circ} \mathrm{F}\right)$ return temperatures. In order to provide the specified clearance between the outer surfaces of pipe insulation and the adjoining trench walls and floor, the overall dimensions of the trench system and the relative location of the underground pipes were varied with the insulation thickness according to dimensions given in Table 1 . An equivalent fue 1 energy cost of $\$ 5.00$ per million Btu was assumed for energy cost calculations along with the use of the material and installation cost data shown in Figure 5. Figure 6 shows that the life-cycle cost is minimal at an insulation thickness of $89 \mathrm{~mm}$ ( 3.5 inches). This is the most cost effective thickness for insulating the underground piping.

The calculated economic thickness should be compared to the thickness required to prevent moisture condensation since condensation occurs when the temperature of cold pipe surface is below the dewpoint temperature of the surrounding trench air. However, an insulation system with a protective jacket can minimize moisture penetration if all jacket joints and seams are correctly sealed. 
A plot of the costs of material and installation, fuel energy cost, and total life-cycle cost of a concrete shallow trench containing two $150 \mathrm{~mm}$ (6-in.) insulated pipes versus the heat loss from these pipes is given in Figure 7, which is a replot of Figure 6. At high values of the system heat loss shown in Figure 7 , the annua 1 cost of material and instal lation is low, but the annual equivalent energy cost is high. Decreasing the heat loss by increasing the thickness of pipe insulation reduces the fuel energy cost but adds to the material and installation costs. At a certain value of pipe heat loss, the sum of the costs of materia 1 and installation, and the fuel energy cost will be a minimum as indicated by the 1 ife-cycle cost curve. Beyond the minimum, the life-cycle cost curve rises because the increased costs of material and installation due to additional insulation thickness is no longer offset by the reduced cost of the system heat loss. As illustrated in the Figure 7, the minimum life-cycle cost was reached at a system heat loss of $146 \mathrm{~W} / \mathrm{m}(152 \mathrm{Btu} / \mathrm{h} \cdot \mathrm{ft})$. The insulation thickness corresponding to this minimum 1 ife-cycle cost heat 1 oss is $89 \mathrm{~mm}$ ( 3.5 inches).

A plot similar to Figure 7 is shown in Figure 8 where the heat supply pipe transported $196^{\circ} \mathrm{C}\left(385^{\circ} \mathrm{F}\right)$ hot water and the return pipe carrying $99^{\circ} \mathrm{C}$ $\left(210^{\circ} \mathrm{F}\right)$ hot water. In Figure 8 , the tota 1 life-cycle cost of the trench underground system involved can be represented by a " $U$ " shaped curve. In this sample case, the 1 ife-cycle cost curve has a minimum that occurs at the pipe heat loss rate of $151 \mathrm{~W} / \mathrm{m}$ (157 Btu/h॰ft). The thickness of insulation layers at this minimum life-cycle cost heat loss is found to be $76 \mathrm{~mm}$ ( 3 inches).

\section{Conclusions}

The calculation of heat loss from a pair of insulated piping system installed in a shallow trench underground heat distribution system has been performed using a computer simulation program based on the finite element method. General formulation of the relevant equations of heat flow and boundary conditions for a two dimensional, steady heat conduction problems are presented. The computationa 1 scheme and the input data required for executing the simulation program are described, and the output from the computer program presented for a sample case.

Life-cycle costing analysis was performed for a typical concrete shallow trench system containing two nominal $152 \mathrm{~mm}(6-i n c h)$ insulated pipes with various insulation thicknesses. It was demonstrated that the least-cost heat loss from the underground pipes or the most economic insulation thickness can be determined for given fluid temperatures based on the results of the cost analysis. The calculated economic insulation thickness should be sufficient to maintain the surface temperature of the insulation above the dewpoint of the surrounding trench air preventing moisture condensation. The procedures for calculating the equivalent energy cost due to the pipe heat loss, and determining the minimum life-cycle cost heat loss for an underground trench system are presented. 
This investigation was conducted under the Tri-Service Building Materials Investigational Program and was jointly sponsored by the Headquarters, U.S. Army Corps of Engineers; U.S. Navy, Naval Facilities Engineering Command; and the U.S. Air Force, Air Force Engineering and Services Center. The author would like to thank Dr. T. Kusuda of NBS for his assistance and permission in using the finite element computer simulation program for heat loss calculations.

\section{References}

1. Pan Am Wor ld Services, Inc., "Heat Distribution Systems Life Cycle Cost Analysis - Comparison Between Direct Buried and Shallow Trench Systems," Report 130319, July 1985.

2. Parsons Corporation, "Life Cycle Cost Analysis - Comparison Between Direct Buried Conduit and Shallow Concrete Trench Underground Heat Distribution Systems," February, 1986.

3. Seger 1 ind, L. J., 'Applied Finite Element Analysis,' John Wiley and Sons, New York, 1976.

4. Zienkiewicz, 0. C. and Morgan, K., 'Finite Elements and Approximation,' John Wiley and Sons, New York, 1983.

5. Torrance, K. E., "Numerical Methods in Heat Transfer," in 'Handbook of Heat Transfer Fundamentals,' Second Edition, edited by Rohsenow, W. M., Hartnett, J. P. and Ganic, E. N., McGraw-Hi11, New York, 1985.

6. Kusuda, T., "FEMTKE - Finite Element Method Computer Program for Underground Heat Distribution System Heat Loss Calculations," a report for Tri-Service Committee on Underground Heat Distribution Systems, January 1984.

7. Kusuda, T., and Achenbach, P. R., "Earth Temperature and Thermal Diffusivity at Selected Stations in the United States," ASHRAE Transactions, Vo1. 71, Part I, PP. 61-75, (1965).

8. Eckert, E. R. G. and Drake, R. M., 'Analysis of Heat and Mass Transfer,' McGraw-Hill, New York, 1972.

9. Holman, J. P., 'Heat Transfer," Fourth Edition, McGraw-Hil1, New York, 1976.

10. U.S. Army Corps of Engineers, Guide Specifications for Military Construction, 'Heat Distribution Systems Outside of Buildings Concrete Shallow Trench Systems,' CEGS-15709, November 1983.

11. Ruegg, R. T., "Life-Cycle Costing Manual for the Federal Energy Management Programs," National Bureau of Standards Handbook 135 , December 1980 .

12. Means Mechanical Cost Data, 7 th Annual Edition, Robert Snow Means Co., Kingston, MA, 1984 . 
13. U.S. Department of Energy, Economic Thickness of Industrial Insulation,' The Fairmont Press Inc., At lanta, GA, 1983.

14. Building Construction Cost Data 1985, 43 rd Annual Edition, Robert Snow Means Co., Kingston, MA, 1985. 
Table 1

Dimensions of Concrete Shallow Trench Systems

for Different Thickness of Pipe Insulation

Pipe

Insulation

Thickness

\begin{tabular}{lllllllllll} 
(inch) & A & B & C & D & E & F & G & H & I \\
\cline { 1 - 2 } 1.0 & 28 & 19 & 40 & 31 & 6 & 6 & 8 & 6 & 11 \\
1.5 & 30 & 20 & 42 & 32 & 6 & 6 & 8 & 6 & 12 \\
2.0 & 32 & 20 & 44 & 32 & 6 & 6 & 8 & 6 & 12 \\
2.5 & 34 & 21 & 46 & 33 & 6 & 6 & 9 & 6 & 12 \\
3.0 & 36 & 22 & 48 & 34 & 6 & 6 & 9 & 6 & 13 \\
3.5 & 38 & 23 & 50 & 35 & 6 & 6 & 10 & 6 & 13 \\
4.0 & 40 & 24 & 52 & 36 & 6 & 6 & 10 & 6 & 14 \\
5.0 & 44 & 26 & 56 & 38 & 6 & 6 & 11 & 6 & 15 \\
6.0 & 48 & 28 & 60 & 40 & 6 & 6 & 12 & 6 & 16
\end{tabular}

Note:

1. Refer to Figure 1 for descriptions of symbols A to I.

2. All dimensions in inches, 1 inch $=2.54 \mathrm{~cm}$ 
Calculated Results of Heat Losses from Two $150 \mathrm{~mm}$ (6-in.) Underground Pipes Inside a Shallow Trench for Pipe Temperatures of 196 and $99 \mathrm{C}(385$ and $210 \mathrm{~F})$

Insulation Thickness (inch)

1.0

1.5

2.0

2.5

3.0

3.5

4.0

5.0

6.0
Heat Loss Rate (Btu/h $\mathrm{ft}^{\circ}$

$\underline{\text { Pipe No. } 1}$ Pipe No. 2 Total

238

94

332

177

74

251

144

62

206

124

54

178

109

48

157

98

44

142

40

130

35

114

32

102

Table 3

\begin{tabular}{|c|c|c|c|}
\hline \multirow{2}{*}{$\begin{array}{l}\text { Insulation } \\
\text { Thickness } \\
\text { (inch) } \\
\end{array}$} & \multicolumn{3}{|c|}{ Heat Loss Rate $(B t u / h \cdot \underline{f t})$} \\
\hline & Pipe No. 1 & Pipe No. 2 & Tota 1 \\
\hline 1.0 & 199 & 157 & 356 \\
\hline 1.5 & 150 & 120 & 270 \\
\hline 2.0 & 122 & 99 & 221 \\
\hline 2.5 & 105 & 85 & 190 \\
\hline 3.0 & 93 & 75 & 168 \\
\hline 3.5 & 84 & 68 & 152 \\
\hline 4.0 & 77 & 63 & 140 \\
\hline 5.0 & 67 & 55 & 122 \\
\hline 6.0 & 60 & 49 & 109 \\
\hline
\end{tabular}


Figure 1. Concrete Shallow Trench Underground Heat Distribution System 


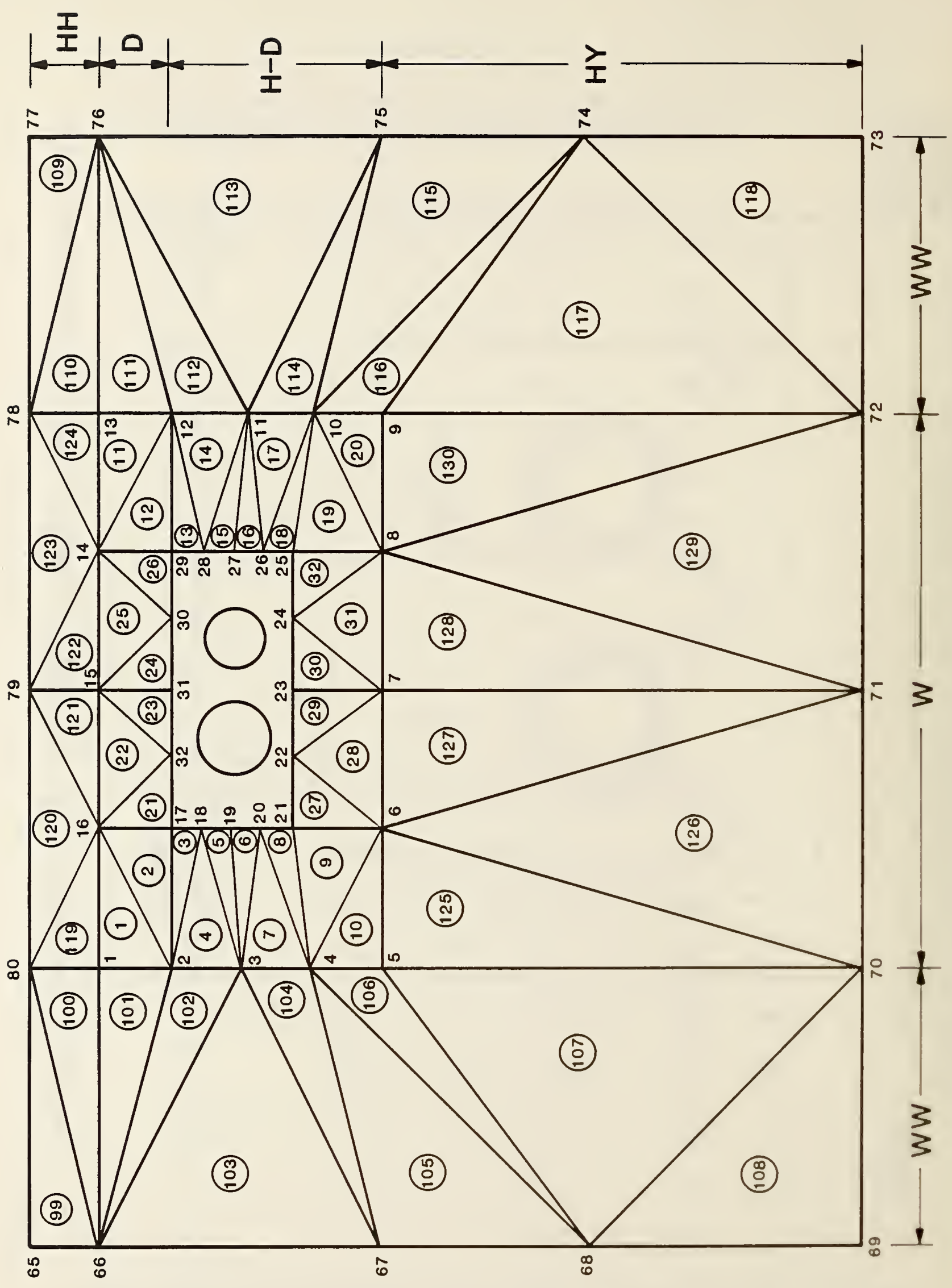

Figure 2. Finite Element Design for the Outer Boundary Earth and Concrete Trench Walls and Cover 


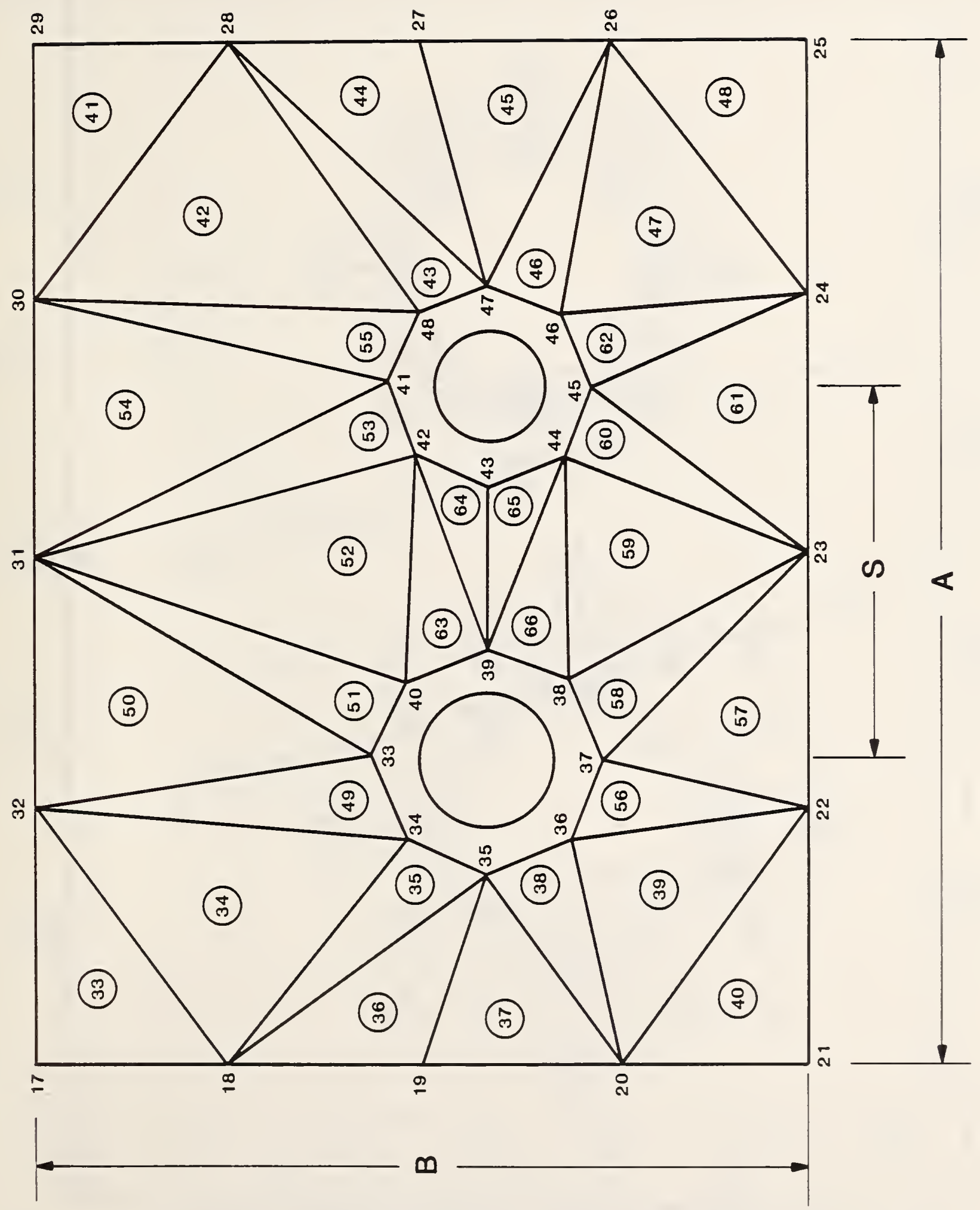

Figure 3. Finite Element Design for Air Space Surrounding the Pipes in Concrete Trench 


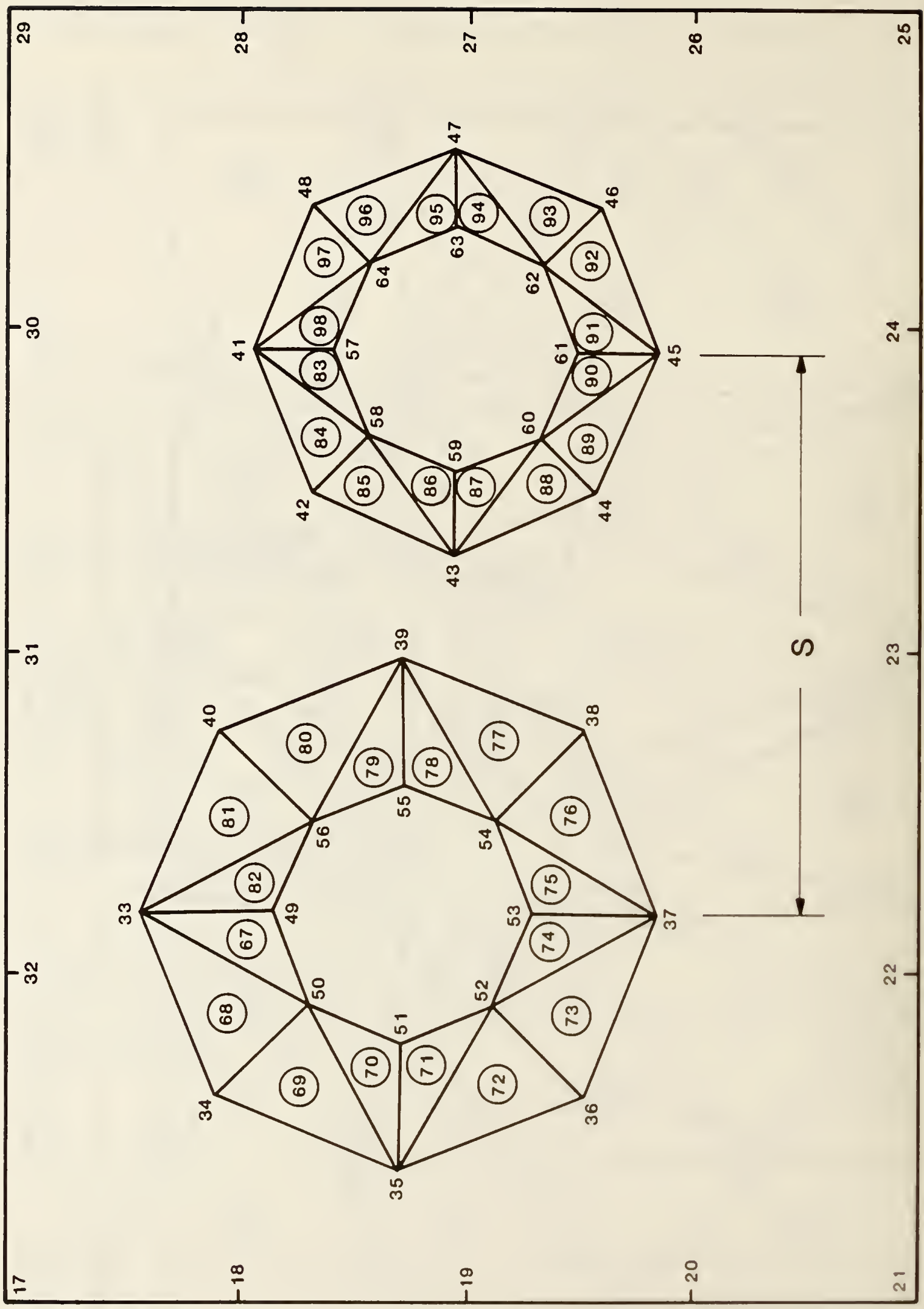

Figure 4. Finite Element Design for the Pipe Insulation and the Outer Surfaces of the Pipes 


\section{$\mathrm{cm}$}

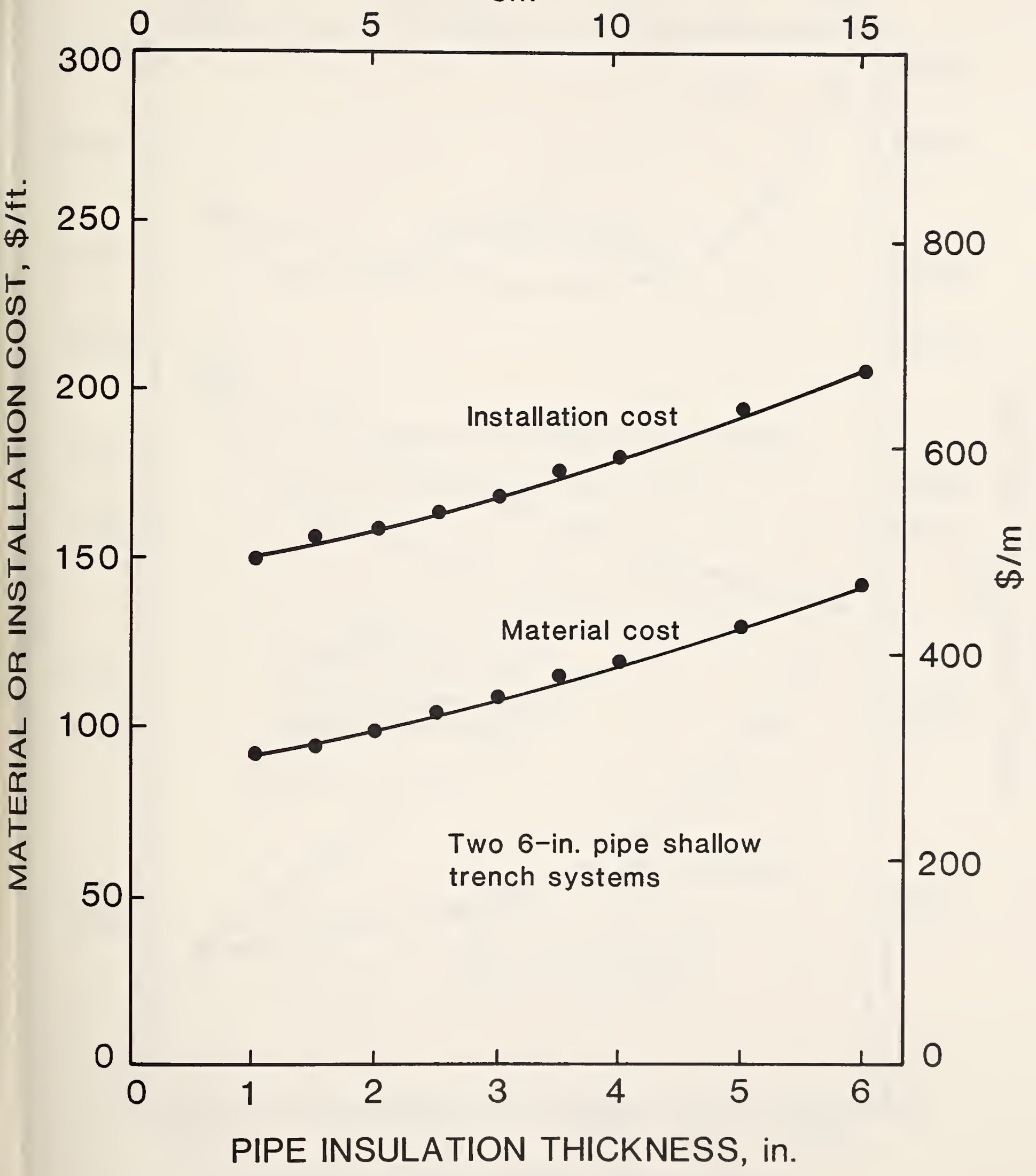

Figure 5. Material and Installation Costs of Two 6-in. Pipe Shallow Trench Systems as a Function of Pipe Insulation Thickness 
$\mathrm{cm}$

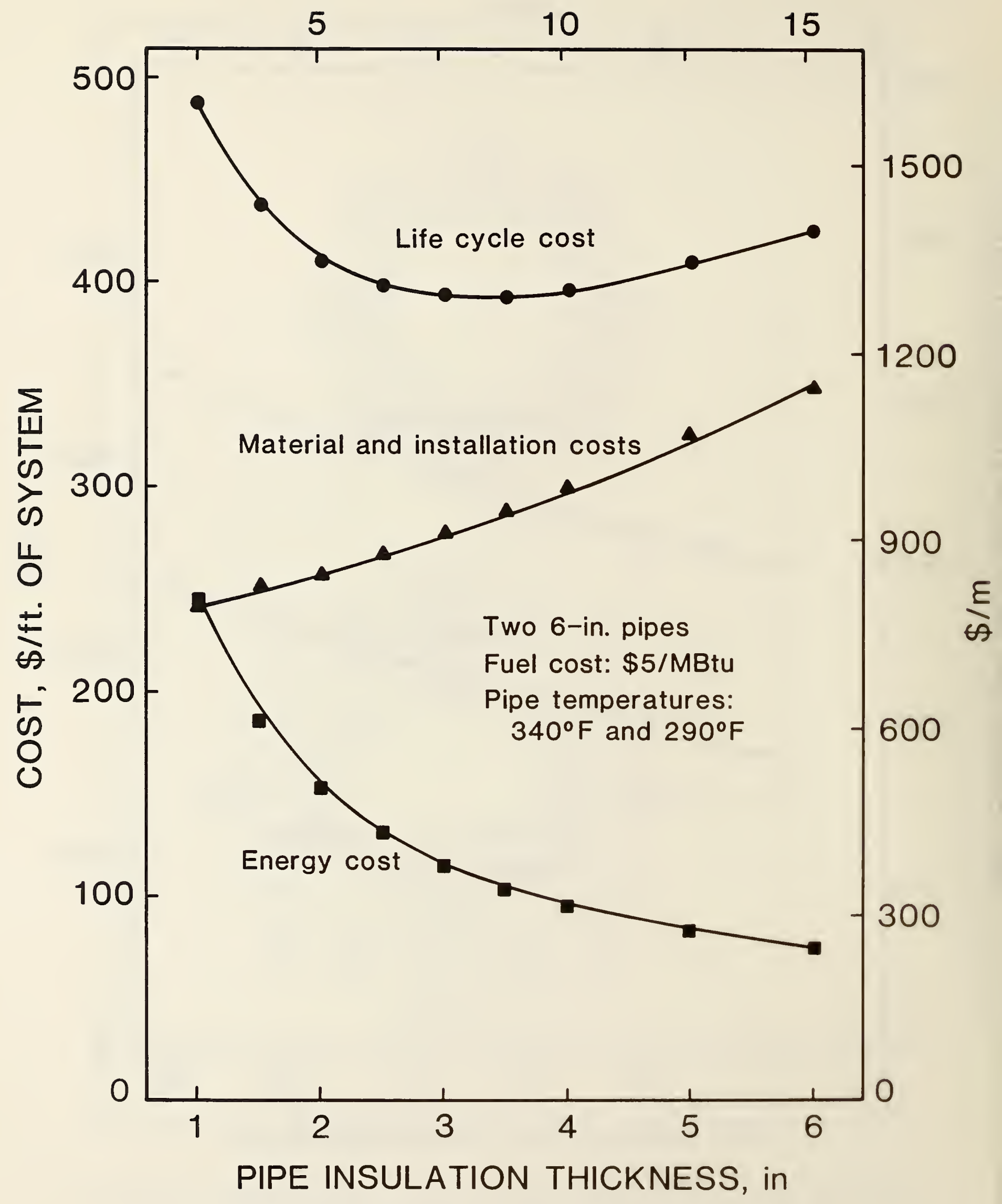

Figure 6. Life-Cycle Cost Analys is for a Shallow Trench System 
$\mathrm{W} / \mathrm{m}$

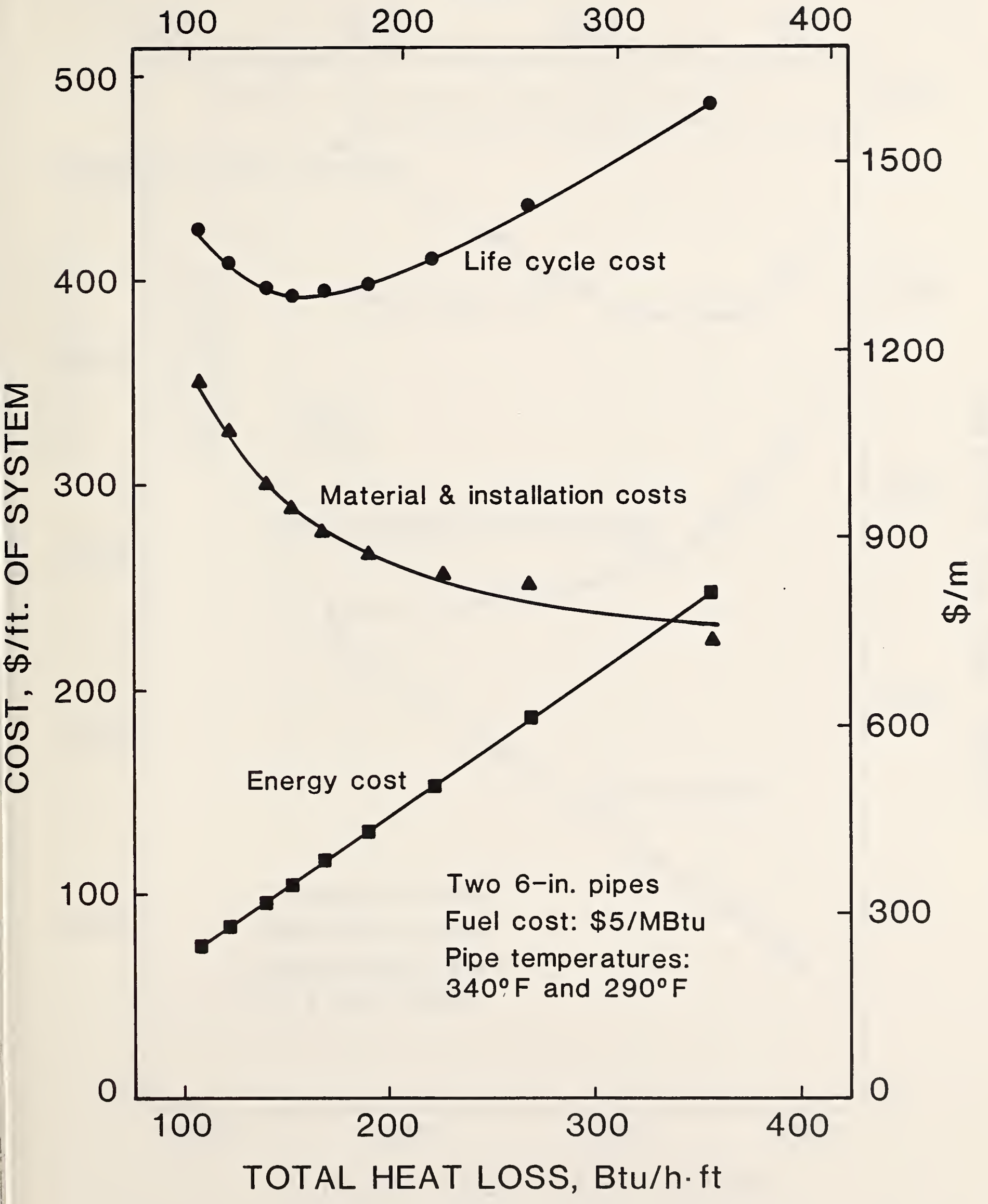

Figure 7. A Plot of the Life-Cycle Cost Versus the Heat Loss from Underground Pipes at 340 and 290 Degree F 
APPENDIX A. The Input Data Files and the Outputs

from the Computer Program on Sample Calculations
A.I A Listing of DAl'Al Input File 1,1
9.7
46.0
385.0
0.44
6.625
3.50
1.30
1.385
10.0
0.50
6.0
56.0
210.0
15.0
6.625
3.50
1.30
56.0
0.417
3.08
20.0
0.00
$1^{\prime} .917$
0.025 


\section{A.2 A Listing of DATA2 Input File}

$\begin{array}{rrrrr}1 & 1 & 16 & 2 & .06 \\ 2 & 16 & 17 & 2 & .06 \\ 3 & 2 & 17 & 18 & .06 \\ 4 & 2 & 18 & 3 & .06 \\ 5 & 3 & 18 & 19 & .06 \\ 6 & 3 & 19 & 20 & .06 \\ 7 & 3 & 20 & 4 & .06 \\ 8 & 4 & 20 & 21 & .06 \\ 9 & 4 & 21 & 6 & .06 \\ 10 & 4 & 6 & 5 & .06 \\ 11 & 14 & 13 & 12 & .06 \\ 12 & 14 & 12 & 29 & .06 \\ 13 & 29 & 12 & 28 & .06 \\ 14 & 28 & 12 & 11 & .06 \\ 15 & 28 & 11 & 27 & .06 \\ 16 & 27 & 11 & 26 & .06 \\ 17 & 26 & 11 & 10 & .06 \\ 18 & 26 & 10 & 25 & .06 \\ 19 & 25 & 10 & 8 & .06 \\ 20 & 8 & 10 & 9 & .06 \\ 21 & 16 & 32 & 17 & .06 \\ 22 & 16 & 15 & 32 & .06 \\ 23 & 32 & 15 & 31 & .06 \\ 24 & 31 & 15 & 30 & .06 \\ 25 & 15 & 14 & 30 & .06 \\ 26 & 30 & 14 & 29 & .06 \\ 27 & 6 & 21 & 22 & .06 \\ 28 & 6 & 22 & 7 & .06 \\ 29 & 22 & 23 & 7 & .06 \\ 30 & 23 & 24 & 7 & .06 \\ 31 & 7 & 24 & 8 & .06 \\ 32 & 24 & 25 & 8 & .06 \\ 33 & 17 & 32 & 18 & .06 \\ 34 & 18 & 32 & 34 & .06 \\ 35 & 18 & 34 & 35 & .06 \\ 36 & 18 & 35 & 19 & .06 \\ 37 & 19 & 35 & 20 & .06 \\ 38 & 20 & 35 & 36 & .06 \\ 39 & 20 & 36 & 22 & .06 \\ 40 & 20 & 22 & 21 & .06 \\ 41 & 30 & 29 & 28 & .06 \\ 42 & 30 & 28 & 48 & .06 \\ 43 & 48 & 28 & 47 & .06 \\ 44 & 47 & 28 & 27 & .06 \\ 45 & 47 & 27 & 26 & .06 \\ 46 & 47 & 26 & 46 & .06 \\ 47 & 46 & 26 & 24 & .06 \\ 48 & 24 & 26 & 25 & .06 \\ 49 & 32 & 33 & 34 & .06 \\ 50 & 32 & 31 & 33 & .06 \\ 51 & 31 & 40 & 33 & .06 \\ 52 & 31 & 42 & 40 & .06 \\ 53 & 31 & 41 & 42 & .06 \\ 55 & 31 & 30 & 41 & .06 \\ & 30 & 48 & 41 & .06\end{array}$




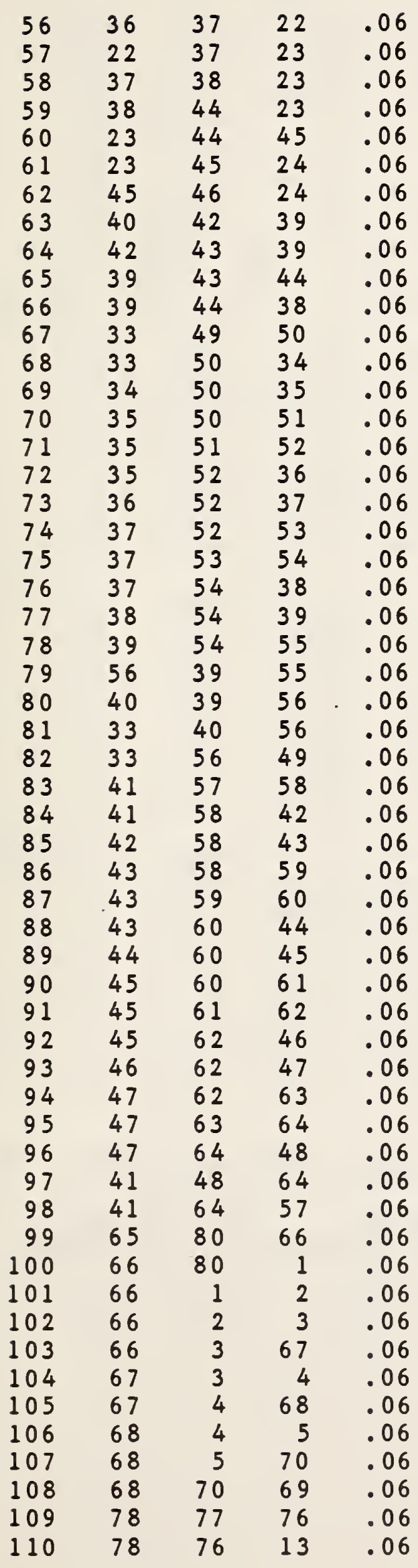




$\begin{array}{rrrrr}111 & 13 & 76 & 12 & .06 \\ 112 & 12 & 76 & 11 & .06 \\ 113 & 11 & 76 & 75 & .06 \\ 114 & 11 & 75 & 10 & .06 \\ 115 & 10 & 75 & 74 & .06 \\ 116 & 10 & 74 & 9 & .06 \\ 117 & 9 & 74 & 72 & .06 \\ 118 & 72 & 74 & 73 & .06 \\ 119 & 80 & 16 & 1 & .06 \\ 120 & 80 & 79 & 16 & .06 \\ 121 & 16 & 79 & 15 & .06 \\ 122 & 15 & 79 & 14 & .06 \\ 123 & 79 & 78 & 14 & .06 \\ 124 & 14 & 78 & 13 & .06 \\ 125 & 5 & 6 & 70 & .06 \\ 126 & 70 & 6 & 71 & .06 \\ 127 & 6 & 7 & 71 & .06 \\ 128 & 71 & 7 & 8 & .06 \\ 129 & 71 & 8 & 72 & .06 \\ 130 & 8 & 9 & 72 & .06\end{array}$


1.3 The Outputs from the Computer Program

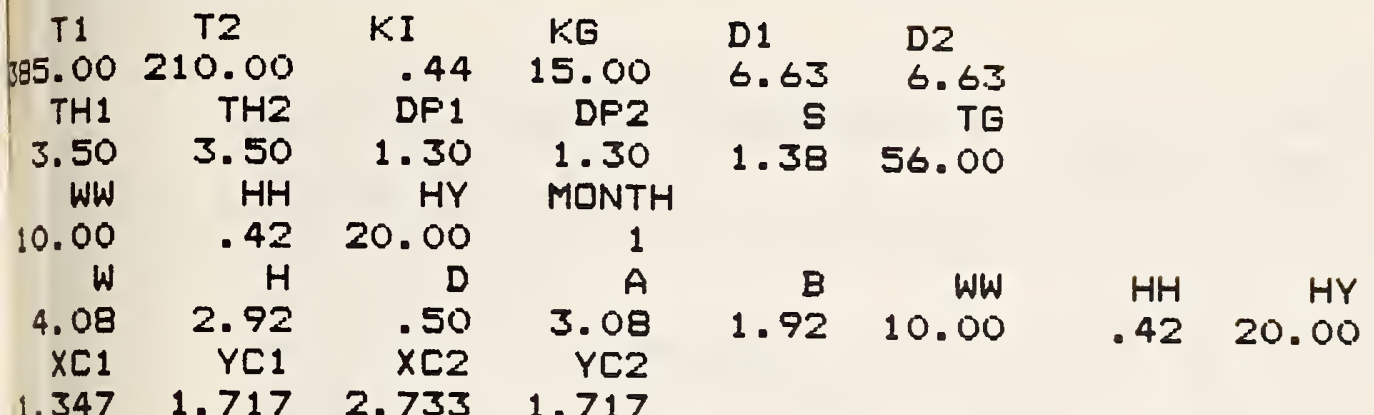

$\begin{array}{llll}1.347 & 1.717 & 2.733 & 1.717\end{array}$

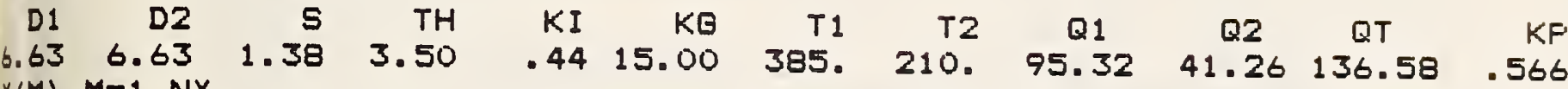
$X(M), M=1, N X$

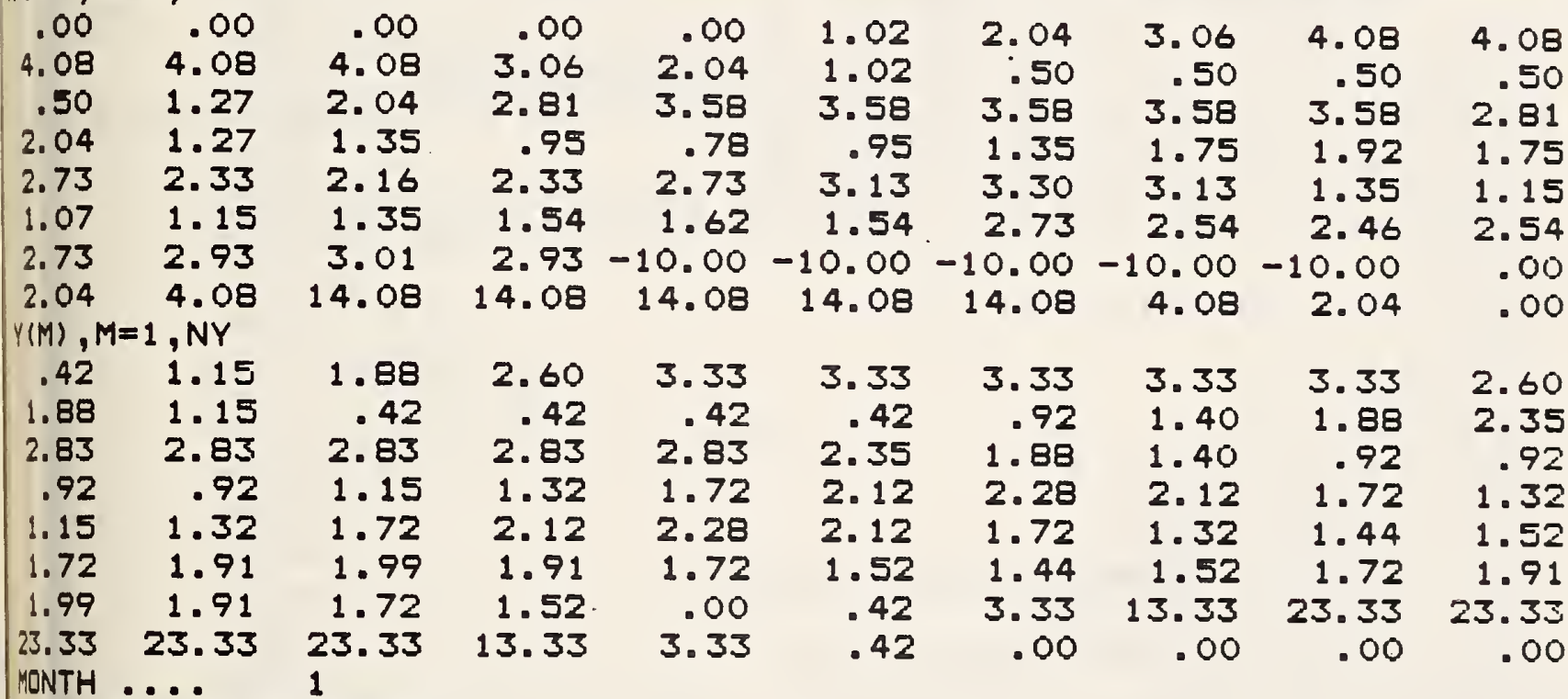

TEMPERATURE ARRAY

$\begin{array}{rrrrrrrrrr}58.37 & 62.45 & 64.72 & 66.07 & 66.10 & 67.21 & 67.32 & 66.62 & 65.21 & 64.92 \\ 63.43 & 61.33 & 57.96 & 60.98 & 62.00 & 62.30 & 66.73 & 70.92 & 72.83 & 72.16 \\ 69.43 & 73.86 & 74.17 & 71.70 & 67.64 & 69.14 & 68.85 & 67.17 & 64.36 & 69.80 \\ 73.82 & 73.29 & 75.06 & 73.41 & 74.32 & 75.30 & 76.77 & 78.13 & 79.45 & 76.92 \\ 71.34 & 75.20 & 78.79 & 76.59 & 73.65 & 71.21 & 69.56 & 69.11 & 385.00 & 385.00 \\ 395.00 & 385.00 & 385.00 & 385.00 & 385.00 & 385.00 & 210.00 & 210.00 & 210.00 & 210.00 \\ 210.00 & 210.00 & 210.00 & 210.00 & 56.00 & 56.00 & 56.00 & 56.00 & 56.00 & 56.00 \\ 56.00 & 56.00 & 56.00 & 56.00 & 56.00 & 56.00 & 56.00 & 56.00 & 56.00 & 56.00\end{array}$

AVERAGE TEMPERATURE DROP ACROSS INSULATION

$T 1=308.83 \quad T 2=\quad 136.82$ DEG $F$

HEAT LOSSES FROM UNDERGROUND PIPES :

Q1 $=98.67 \quad Q 2=\quad 43.71 \quad \mathrm{QT}=\quad 142.39 \mathrm{BTU} / \mathrm{H}-\mathrm{FT}$ 


\section{PROGRAM FEUHDS}

THIS IS A PROGRAM FOR ANALYSIS OF ONDERGROOND SYSTEM HEAT LOSS

BASED ON FINITE ELEMENT METHOD

SUBRODTINES CALLED: PIPE2, TWOPIP, TGO, SOILR, TGXX, SOLVP, AND PI PEBL

INPUT DATA FILES: DATA1 AND DATA2

OUTPUT DATA FILE: PLTDTA

$X(I): X-C O O R D I N A T E$ OF NODAL POINT I, IN FT

$Y(I)$ : $Y$-COORDINATE OF NORAL POINT I, IN FT

$I, J, K$ NODAL POINTS OF ELEMENT M

$M$ ELEMENT INDEX

C THERMAL CONDUCTIVITY, BTD-IN/HR/FT**2/F

L THICKNESS OF THE ELEMENT, FT

C

WHEN TEMPERATURE ( $T(I), I=M Z, N X)$ ARE RNOWN MZ.NE.O.

DIMENSION $Q(130), T(130), X(130), Y(130), K R(130,130)$

DIMENSION IZ (130), JZ(130), KZ(130), AS(130), B $2 \mathrm{IZ}(130), \mathrm{B} 3 \mathrm{IZ}(130), \mathrm{B} 2 \mathrm{JZ}$

$\&(130), \mathrm{B} 2 \mathrm{KZ}(130), \mathrm{B} 3 \mathrm{JZ}(130), \mathrm{B} 3 \mathrm{KZ}(130)$

DIMENSION CC(130), TGX $(12,5), Q Q(130)$

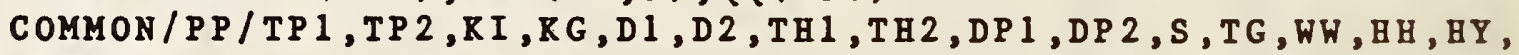

\& MONTH

REAL $L, R K, K I, K G, K I X, K T C T, R A S P$

TRTK $=0$.

$P I=4 . * A T A N(1$.

71 CONTINUE

OPEN $\left(8, F I L E={ }^{\circ}\right.$ DATA1')

OPEN $\left(6, F I L E={ }^{-} P R N^{-}\right)$

OPEN $\left(9\right.$, FILE $={ }^{-}$DATA2')

OPEN $\left(10\right.$, FILE $={ }^{\prime}$ PLTDTA', STATUS $={ }^{\prime}$ NEW' $)$

C READ IN MREPT AND ITREN

READ $(8,200, E R R=2000)$ MREPT, ITREN

200 FORMAT (I $5,1 \mathrm{X}$, I 4$)$

$72 \quad M I 1=32$

$M I 2=99$

IF (ITREN.EQ.0) GO TO 50

MI $1=66$

MI $2=99$

50 CONTINOE

C READ MONTH OF INTEREST AND ICALB

READ $(8,250)$ MONTH, ICALB

250 FORMAT (2I 5 )

IF(ITREN.NE.1) GO TO 73

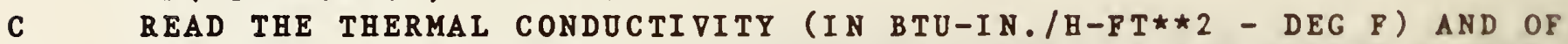

C THICKNESS (IN INCHES) OF CONCRETE WALL FOR SHALLOW TRENCH SYSTEM. READ $(8,260)$ RTCT, TRTK

260 FORMAT (2F 10.4$)$

C. READ EQOIVALENT THERMAL CONDOCTIVITY OF AIR SPACE SURROUNDING THE

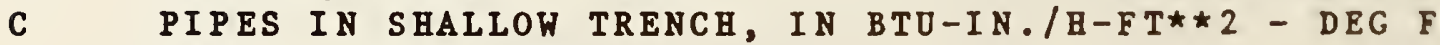

READ $(8,265)$ RASP

265 FORMAT (F10.5)

73 CONTINOE

CALL PIPE2( $X, Y$, I TREN, TRTR )

CALL TWOPIP $(1, I T R E N)$

$\mathrm{NX}=80$

$N Y=80$

$M Z=49$

$M X=130$ 


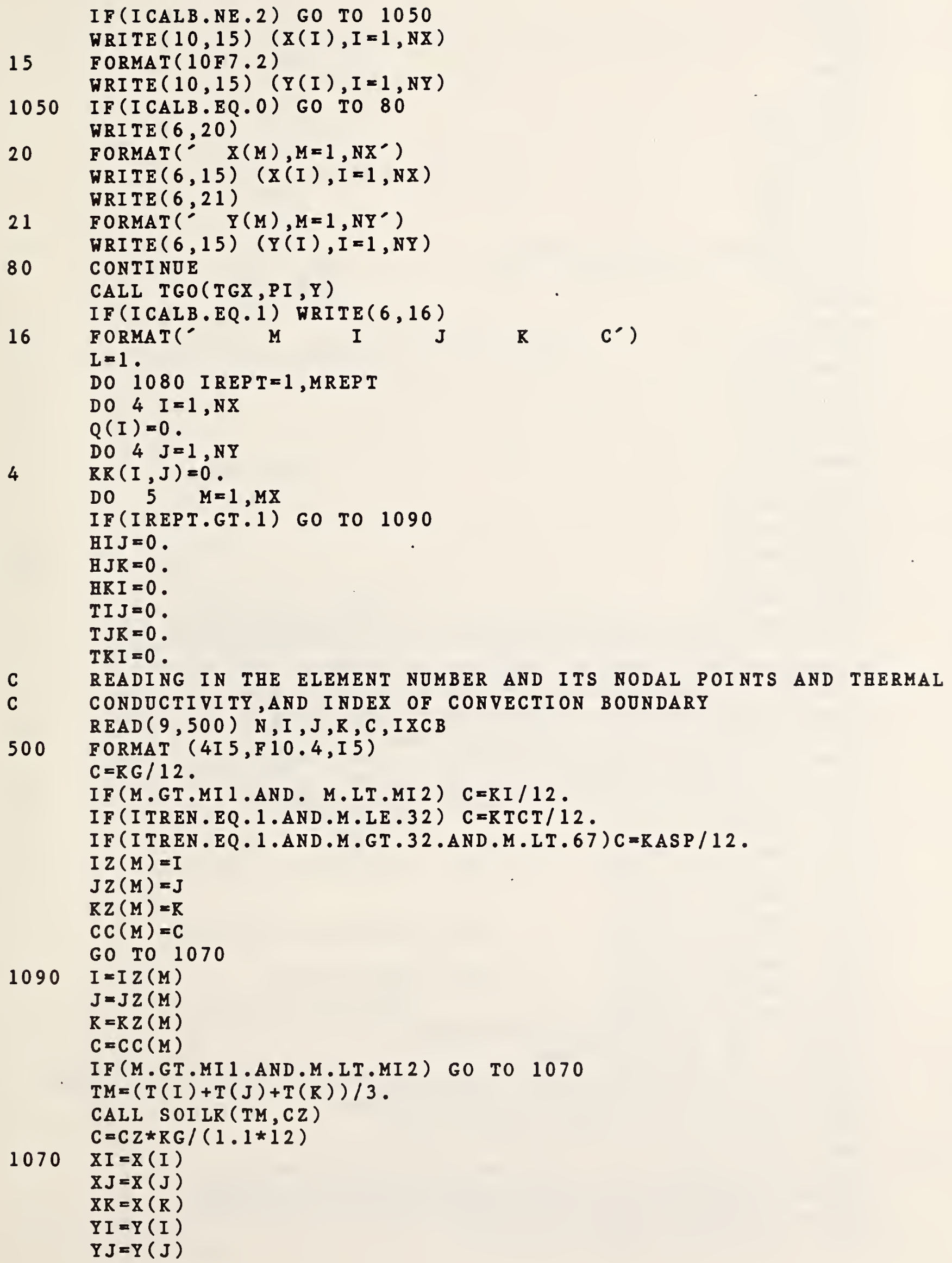




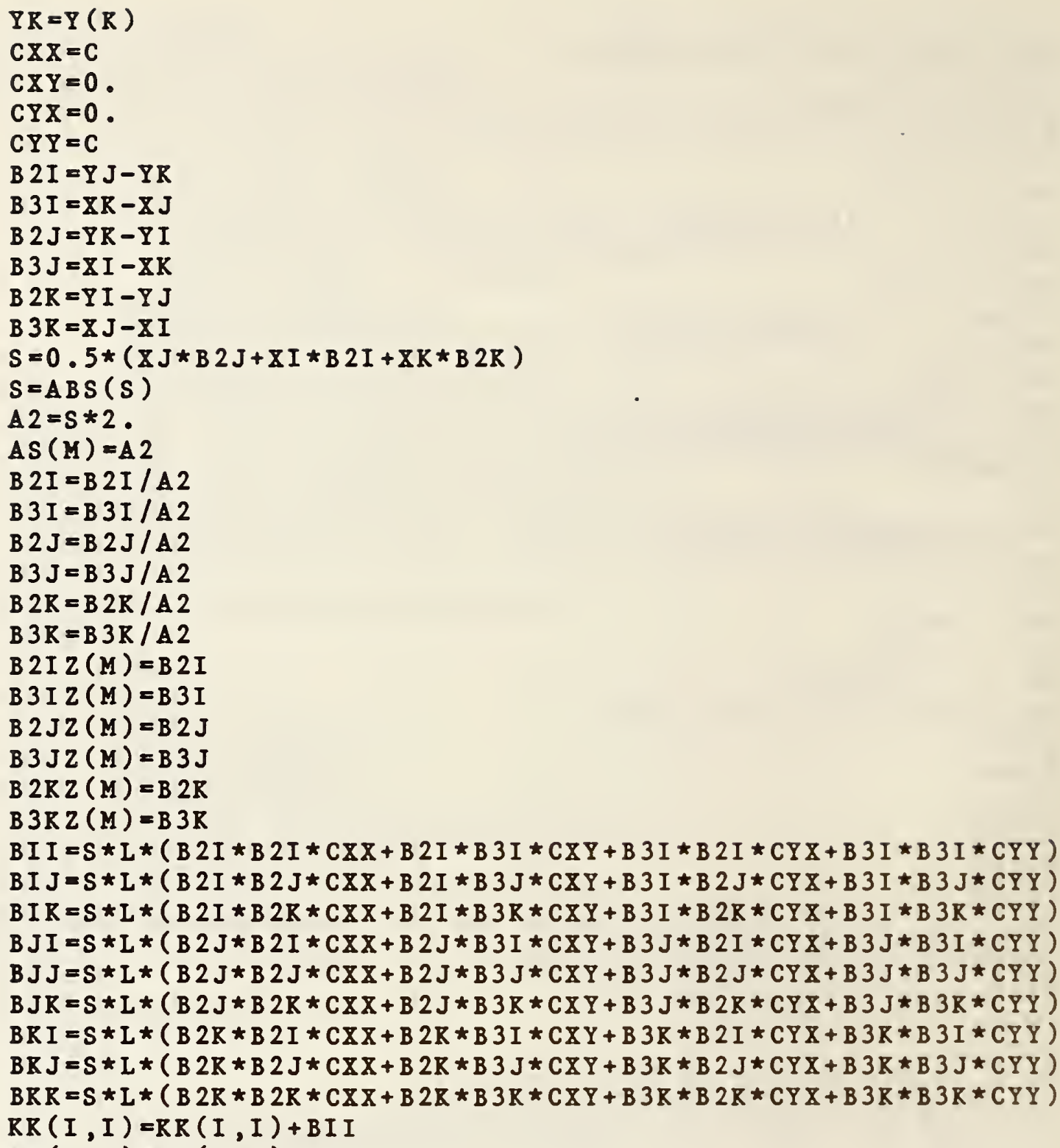


$\operatorname{RK}(I, J)=\mathrm{HHI} J+\mathrm{RR}(I, \mathrm{~J})$

$R R(I, R)=H H R I+R K(I, R)$

$R R(J, I)=B B I J+R K(J, I)$

$R K(J, J)=H H I J * 2+H H J R * 2 .+R R(J, J)$

$R R(J, R)=B H J R+R R(J, R)$

$\operatorname{RR}(R, I)=H H R I+R K(R, I)$

$\mathrm{RR}(\mathrm{K}, \mathrm{J})=\mathrm{H} H \mathrm{H} \mathrm{K}+\mathrm{RK}(\mathrm{R}, \mathrm{J})$

$\mathrm{KR}(\mathrm{R}, \mathrm{K})=\mathrm{H} H J \mathrm{H} * 2 .+\mathrm{HHR} I * 2 .+\mathrm{RK}(\mathrm{K}, \mathrm{K})$

HHI J $=T I J * 3 . * H H I J$

$H H J R=T J R * 3 . * H H J R$

$H H R I=T R I * 3 . * H H R I$

$Q(I)=Q(I)+H H I J+H H R I$

$Q(J)=Q(J)+H H I J+H H J R$

$Q(R)=Q(R)+H H J R+H H R I$

$800 \operatorname{IF}(\operatorname{ICALB} . \mathrm{BQ} .1)$ WRITE $(6,9) \mathrm{M}, I, J, R, C$

IF (ICALB.EQ.2) WRITE $(10,9) \mathrm{M}, \mathrm{I}, \mathrm{J}, \mathrm{R}, \mathrm{C}$

9 FORMAT (4I5, F10.4)

5. CONTINOE

$M Z Z=M Z-1$

$M Z 8=M Z+7$

DO $900 \quad I=M Z, M Z 8$

$T(I)=T P 1$

$I I=I+8$

$T(I I)=T P 2$

900 CONTINUE

MMZ $16=M Z+16$

DO $1080 \mathrm{MJ}=$ MONTH, MONTH

CALL TGXX (T, TGX, MJ)

DO $77 \mathrm{I}=1, \mathrm{MZZ}$

SOM $=0$.

DO $78 \mathrm{~J}=\mathrm{MZ}, \mathrm{NX}$

$78 \quad \mathrm{SUM}=\mathrm{S} U \mathrm{OM}+\mathrm{KR}(\mathrm{I}, \mathrm{J}) * \mathrm{~T}(\mathrm{~J})$

$77 \quad Q Q(I)=Q(I)-S U M$

WRITE $(6,10)$ MJ

10 FORMAT(' MONTH ...., I5)

IF (ICALB.EQ.1) WRITE $(6,6)$

6 FORMAT (6X, $\mathrm{QQ}$ ARRAY')

IF (ICALB.EQ.1) WRITE $(6,7) \quad(Q Q(I), I=1, N X)$

FORMAT (10F7.2)

$\mathrm{NXX}=\mathrm{NX}$

CALL SOLVP( $M Z Z, M Z, R R, Q Q, T, 130)$

WRITE $(6,14)$

14 FORMAT (' TEMPERATURE ARRAT')

WRITE $(6,7) \quad(T(I), I=1, N X)$

IF (ICALB.EQ.2) WRITE $(10,7)(T(I), I=1, N X)$

$\mathrm{R} 1=\mathrm{D} 1 / 24$.

$\mathrm{R} 2=\mathrm{D} 2 / 24$.

$\mathrm{TH} 1 \mathrm{X}=\mathrm{TH} 1 / 12$.

$\mathrm{TH} 2 \mathrm{X}=\mathrm{T} \mathrm{B} 2 / 12$.

I S $1=49$

I S $2=57$

$\mathrm{R} I \mathrm{X}=\mathrm{R} I / 12$.

CALL PIPEHL ( T, R1, R2, TH1X, TH $2 X, I S 1, I S 2, R I X, 8, Q T X)$

1080 CONTINUE

GOTO 2010 
2000 HRITE $(6,2005)$

2005 FORMAT (IX, 'THERE $\triangle R E$ SOME ERRORS IN DATA')

2010 STOP

END

SOBRODTIRE TGO(TGX,PI, Y)

THIS SOBROOTIRE CALCOLATES THE ONDISTORBED EARTH TEMPERATORES $\triangle T$ TARIOOS DEPTES

DIMENSIOR TGX $(12,5), \bar{I}(1)$

READING IN THE $\triangle N O A L$ AVERAGE TEMPERATORE ARD $\triangle M P L I T O D E$ OP TBE

MONTHLY HORMAL TEMPERATURE CYCLE OF THE SITE, IN DEG $P$, $\triangle N D$

THERMAL DIPPOSIVITY OF SOIL, IN $P T \star \star 2 / B$.

READ $(8,300) \triangle 0, B O, D I P F$

300 FORMAT $(3 \mathrm{~F} 10.4)$

$H=2 . * P I / 12$.

$H Z=2 * P I /(8760 \star D I F P \star 2)$

$\mathrm{ZZ}=\mathrm{SQRT}$ ( $\mathrm{HZ}$ )

DO $1 I=1,12$

DO $1 \mathrm{~J}=1,5$

$Z=Z Z * I(64+J)$

$1 \operatorname{TGX}(I, J)=\Delta O+B O * B X P(-Z) * \operatorname{SIN}(H *(I-3)-Z)$

RETORN

BND 
SUBROUTINE PIPE2( $X, Y$, ITREN, TRTK)

* THIS SUBROUTINE GENERATES $X$ AND $Y$-COORDINATES OF NODAL POINTS FOR

* THE TWO PIPE SYSTEM

REAL RII, KIG,KI, KG

DIMENSION $X(1), Y(1)$

COMMON/PP/T1,T2,RII, RIG,PI 1,PI 2, THI1, THI2, B 1, B 2, S, TG,

\& WW, HH, HY, MONTH

C READ TEMPERATORE OF PIPES 1 AND 2, IN DEG $F$

READ $(8,300)$ T 1, T 2

300 FORMAT (2F10.3)

C READ THERMAL CONDOCTIVITY OF THERMAL INSOLATION AND SOIL,

C RESPECTIVELY, IN BTD-IN./H-FT**2 - DEG F

READ $(8,310)$ RII, KIG

310 FORMAT (2F 10.4$)$

C READING IN THE OOTSIDE DIAMETERS OF STEEL PIPES 1 AND 2 , IN INCHES READ $(8,310)$ PI 1, PI 2

C READING IN THE THICRNESS OF THERMAL INSOLATION OSED FOR PIPES 1

C AND 2, RESPECTIVELT, IN INCBES

READ $(8,310)$ THI 1, THI 2

C READ THE DEPTHS FROM GROUND SURFACE TO THE CENTERS OF PIPES 1 AND

C 2 , RESPECTIVELY, IN FT.

READ $(8,310)$ B $1, B 2$

C READING IN THE SEPARATION DISTANCE (IN FT.) OF THE PIPE CENTERS,

C AND THE AVERAGE EARTH TEMPERATORE, IN DEG F.

READ $(8,310)$ S,TG

C READ IN THE WIDTH AND DEPTHS OF EARTH REGIONS SORRODNDING THE

C UNDERGROUND SYSTEM, IN FT.

READ $(8,315)$ WW, HH, HY

315 FORMAT (3F10.4)

WRITE $(6,44)$ T1, T2,RII, RIG,PI1,PI 2

44 FORMAT(" T1 T2 RI KG

WRITE $(6,55)$ THI 1, THI 2, B $1, B 2, S, T G$

55

F ORMAT (

TH 1 TH 2 DP 1 DP 2

D 1

$\mathrm{D} 2 \cdot(6 \mathrm{~F} 7.2)$

WRITE $(6,66)$ WW, HH, HY, MONTH

66 FORMAT(' WW HH HY MONTH'/3F7.2,I7)

C READ IN THE DEPTH OF EARTH COVER, THE WIDTH AND HEIGHT OF TRENCB

C OR LOOSE-FILL.

$\operatorname{READ}(8,315) \quad D, A, B$

$W=2 * A$

$\mathrm{H}=2$.*B $\mathrm{B}+\mathrm{D}$

$P I=P I 1 / 12$.

$\mathrm{R} I=\mathrm{P} I * 0.5$

$P 2=P I 2 / 12$.

$R 2=P 2 * 0.5$

$R I=R I I / 12$.

$\mathrm{KG}=\mathrm{RIG} / 12$.

IF (I TREN.NE.1) GO TO 67

$W=A+2 * T R T R / 12$

$\mathrm{H}=\mathrm{B}+2 * \mathrm{TR} \mathrm{TR} / 12$

67 WRITE $(6,22)$ W, B, D, A, B, WW, BH, HY

$\mathrm{B} 1=\mathrm{B} 1+\mathrm{BH}$

B $2=B 2+B B$

22

FORMAT (

$\left.\&^{\prime} /, 8 \mathrm{~F} 7.2\right)$

H

D

A

B

WW

$\mathrm{HH}$

HY

$P I=4$ * $\operatorname{ATAN}(1$. 


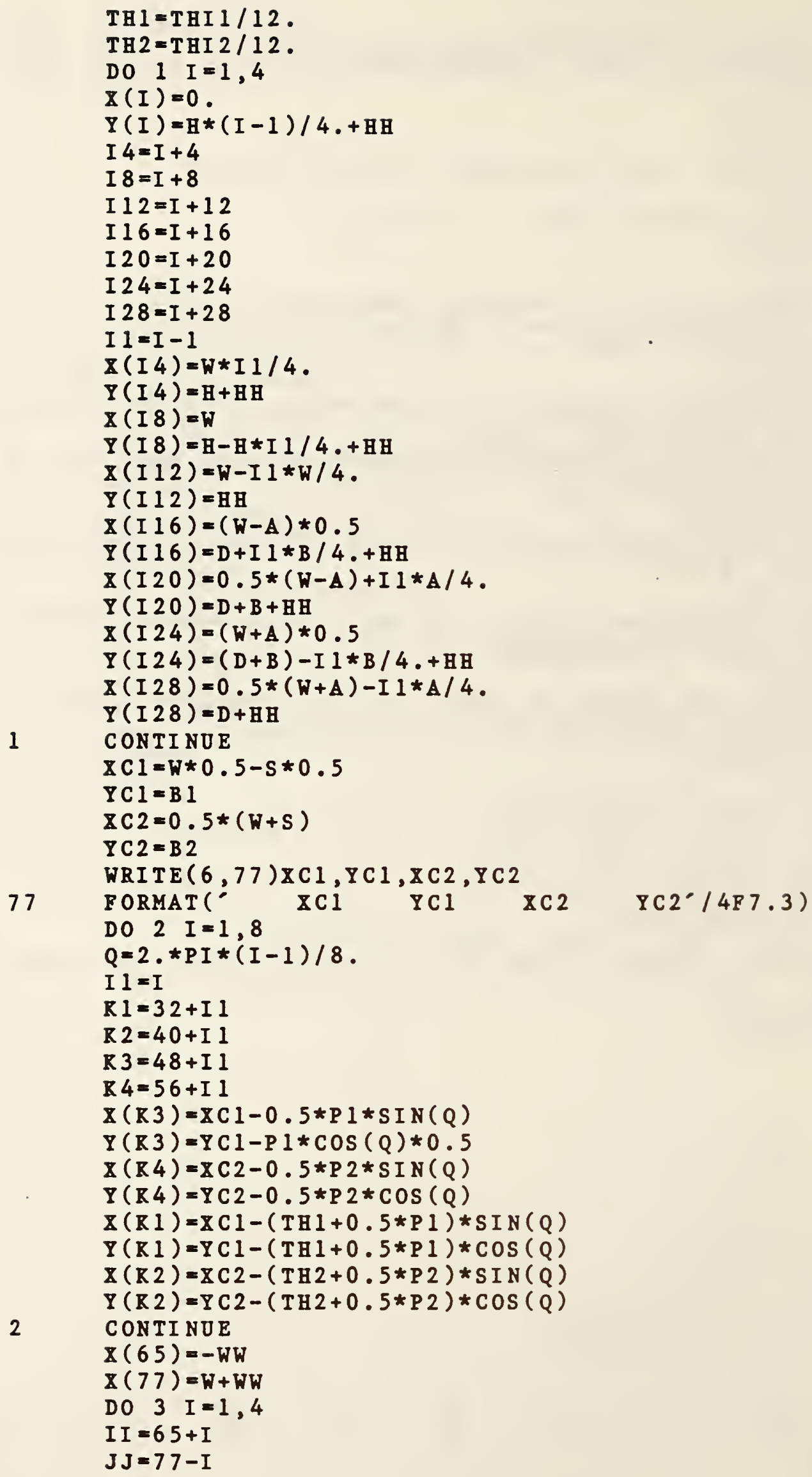


$X(I I)=X(65)$

$X(\mathrm{JJ})=\mathrm{X}(77)$

3 CONTINOE

$X(70)=X(5)$

$X(80)=X(70)$

$X(71)=x(7)$

$x(72)=x(9)$

$X(78)=X(72)$

$X(79)=X(71)$

DO $5 \quad I=77,80$

$5 \quad Y(I)=0$.

$Y(65)=0$

$Y(66)=Y(1)$

$Y(76)=Y(66)$

DO $6 \quad I=69,73$

6

$\mathrm{Y}(\mathrm{I})=\mathrm{HH}+\mathrm{H}+\mathrm{HY}$

$Y(67)=Y(5)$

$Y(75)=Y(67)$

$Y(68)=(Y(5)+Y(70)) * 0.5$

$Y(74)=Y(68)$

RET URN

END 
SOBROOTINE TWOPIP (IREPT, ITREN)

* THIS SUBROUTINE DETERMINES TWO PIPE HEAT LOSS TO ONDERGROUND COMMON/PP/T 1, T 2, ZRI, ZRSI, DA 1, DA $2, \mathrm{THI} 1, \mathrm{THI} 2, \mathrm{D} 1, \mathrm{D} 2, \mathrm{AX}, \mathrm{TG}$ $\&, W W$, B日, BY, MONTB

$P I=4 . * A T A N(1$.

$\mathrm{X} 1=2$ * $* \mathrm{PI}$

$R 1=D A 1 / 24$.

$R 2=D A 2 / 24$.

$T B 1 X=T H I / 12$.

TH $2=\mathrm{TH} I 2 / 12$.

$\mathrm{ZR} 1=\mathrm{ZRI} / 12$.

$\mathrm{ZR} 2=\mathrm{ZR} 1$

$\mathrm{D} 1=\mathrm{D} 1+\mathrm{B} B$

$D 2=D 2+B H$

$\mathrm{ZRS}=\mathrm{ZRSI} / 12$.

WRITE $(6,6)$

DO $5 \mathrm{I}=1$, I REPT

$T H 1=T H 1 X+0.1 *(I-1)$

$T$ H $2=T H 1$

$A=R 1+R 2+T H 1+T H 2+0.05$

$T$ HI $1=T H 1 * 12$.

IF (ITREN.EQ.1) $\quad A=A X$

$\mathrm{C} 1=\mathrm{X} 1 * \mathrm{ZR} 1 / \mathrm{LOG}((\mathrm{R} 1+\mathrm{TH} 1) / \mathrm{R} 1)$

$\mathrm{C} 2=\mathrm{Z} 1 * \mathrm{ZR} 2 / \mathrm{LOG}((\mathrm{R} 2+\mathrm{TH} 2) / \mathrm{R} 2)$

$\mathrm{P} 11=1+\mathrm{C} 1 /(\mathrm{X} 1 * \mathrm{ZRS}) * \operatorname{LOG}((2 * \mathrm{D} 1) /(\mathrm{B} 1+\mathrm{TH} 1))$

$P 12=C 2 /(X 1 * Z K S) * \operatorname{LOG}((A * A+(D 1+D 2) * \star 2) /(A * A+(D 1-D 2) \star \star 2)) \star 0.5$

P $21=C 1 /(X 1 * Z R S) \star \operatorname{LOG}((A \star A+(D 1+D 2) \star \star 2) /(A \star A+(D 1-D 2) \star \star 2)) \star 0.5$

$\mathrm{P} 22=1+\mathrm{C} 2 /(\mathrm{X} 1 * \mathrm{ZRS}) * \operatorname{LOG}((2 * \mathrm{D} 2) /(\mathrm{R} 2+\mathrm{TH} 2))$

$D E L=P 12 * P 21-P 11 * P 22$

$\mathrm{ZRP} 1=C 1 *(\mathrm{P} 12-\mathrm{P} 22) / \mathrm{DEL}$

$\mathrm{ZKP} 2=\mathrm{C} 2 *(\mathrm{P} 21-\mathrm{P} 11) / \mathrm{DEL}$

$T P 1=(P 12 * T 2-P 22 * T 1) /(P 12-P 22)$

TP $2=($ P 21*T1-P 11*T2)/( P 21-P 1 1)

$Q 1=Z R P 1 *(T P 1-T G)$

$Q 2=Z K P 2 *(T P 2-T G)$

$Q T=Q 1+Q 2$

$T M=(T 1+T 2) * 0.5$

$\mathrm{ZK}=(\mathrm{QT}) /(\mathrm{TM}-\mathrm{TG})$

WRITE $(6,3)$ DA 1, DA $2, A, T H I 1, Z R I, Z R S I, T 1, T 2, Q 1, Q 2, Q T, Z R$ FORMAT ( 6 F $6.2,2$ F $6.0,3$ F 7.2, F 6.3$)$

FORMAT (

\& Q2 QT

CONTINUE

D 1

D 2

$\mathrm{S}$

TH $\mathrm{KI}$

R G

T 1

T 2

Q 1

RET URN

END 
SOBROUTIRE SOILK (T, ZR )

* THIS ROUTINE DETERMIRES THERMAL CONDOCTIVITY OF SOIL

* $\triangle S$ ISONCTION OF TEMPERATORE

RBAL R(14)

DIMENSION TX(14)

DATA $R / 1.1,1.1,1.1,1.0,0.4,0.31,0.25,0.19,0.15,0.11,0.09,0.07$, $\& 0.05,0.05 \%$

DO $1 I=1,14$

$1 \quad T X(I)=50 .+(I-1) \star 25$.

IF(T.GT.TX(1)) GO TO 7

$\mathrm{ZR}=1.1$

GO TO 5

7 IF (T.IT.TX(14)) GO TO 6

$\mathrm{ZX}=0.05$

GO TO 5

$6 \quad$ DO $2 I=1,13$

$T I=T-T X(I)$

$I F(T I . H B .0)$ GO TO 3

$2 \mathrm{Z}=\mathbf{K}(\mathrm{I})$

GO TO 5

3 CONTIROE

$T 2=T-T X(I+1)$

IF(T2.IE.0.) GO TO 4

$2 R=R(I+1)$

GO TO 5

CORTIROE

$P=T 1 \star T 2$

IF (P.GT.O) GO TO 2

$Z K=K(I+1)+I 2 *(I(I+1)-I(I)) / 25$.

GO TO 5

2 CONTIROB

5 RETURN

ERD

SUBROOTIRE TGXX(T, TGX, MORTE)

* THIS SUBRODTINE PROVIDES OUTER BOUNDARY TEMPERATURES OF EARTB REGION DIMENSION $T(1), \operatorname{TGZ}(12,5)$

$T(65)=T G X($ HONTH, 1$)$

DO $1 I=77,80$

$T(I)=T(65)$

1 CONTIMOE

$T(66)=T G X($ MONTH , 2)

$T(76)=T(66)$

$T(67)=\operatorname{TGX}($ MONTH, 3$)$

$T(75)=T(67)$

$T(68)=\operatorname{TGX}($ MONTH, 4$)$

$T(74)=T(68)$

$T(69)=\operatorname{TGX}($ HONTH, 5$)$

DO $2 I=70,73$

$2 \quad T(I)=T(69)$

RET OBN

BND 
SOBROOTINE SOLVP(M,N,C,D,X,I)

* THIS SUBROUTINE SOLVES THE SIMULTANEOUS EQUATIONS

DIMENSION $A(100,101), C(I, 1), D(1), X(1)$

DO 10 IX $X=1, M$

$10 \quad A(I X, I Y)=C(I X, I Y)$

$A(I X, I Y)=C(I X$
DO 20 I $2=1, M$

$20 \quad A(I 2, N)=D($ I 2$)$

$L=1$

$30 \quad A A=A(L, L)$

DO $40 \quad \mathrm{~K}=\mathrm{I}, \mathrm{N}$

$40 \quad A(L, R)=A(L, R) / A A$

DO $60 \quad R=1, M$

IF (R.EQ.L) GO TO 60

$A A=-A(K, L)$

DO 50 IA $=\mathrm{L}, \mathrm{N}$

$50 \quad A(R, I A)=A(R, I A)+A A * A(L, I A)$

60 CONTINUE

$\mathrm{L}=\mathrm{L}+1$

IF (I.LE.M) GO TO 30

DO 70 IP $=1, M$

$70 \quad X(I P)=A(I P, N)$

RET ORN

END 
SUBROUTINE PIPEHL(T, R1, R2, TH1, TH2, IS I, IS 2, ZRS, N1, QT)

* THIS SUBROUTINE CALCULATES THE AVERAGE TEMPERATURE DROPS ACROSS THE

* PIPE INSULATIONS AND THE RATES OF HEAT LOSS FROM THE UNDERGROND

* PIPES IN TRENCH STSTEM

DIMENSION T(1)

$P I=4 . \star \operatorname{ATAN}(1$.

$S O M I=0$.

$S U M 2=0$.

DO $1 \quad I=1, N 1$

$\mathrm{R} 1=\mathrm{IS} 1+(\mathrm{I}-1)$

R2 $2=I S 2+(I-1)$

$\mathrm{R} 3=\mathrm{R} 1-16$

R $4=R 2-16$

SUM $1=S U M 1+T(R 1)-T(R 3)$

$S O M 2=S O M 2+T(R 2)-T(R 4)$

1 CONTINOE

$T 1=S O M 1 / N 1$

$T 2=S O M 2 / N 1$

HRITE $(6,3)$ T 1, T 2

3 FORMAT $/ / /$ AVERAGE TEMPERATURE DROP ACROSS INSULATION

$\& / /^{\prime} \mathrm{T} 1={ }^{\prime}, \mathrm{F} 10.2,^{\prime} \quad \mathrm{T} 2={ }^{\prime}, \mathrm{F} 10.2,^{\prime}$ DEG $\left.\mathrm{F}^{\prime}\right)$

$Q 1=Z R S * 2 . * P I * T 1 / L O G((R 1+T H 1) / R 1)$

$Q 2=Z R S * 2$. *PI *T2/LOG ( (R2+TH2)/R2)

$Q T=Q 1+Q 2$

VRITE $(6,2) Q 1, Q 2, Q T$

2 FORMAT( $38, "$ HEAT LOSSES FROM ONDERGROOND PIPES : $/ / /^{\prime} \quad Q 1={ }^{\prime}, F 10.2$,

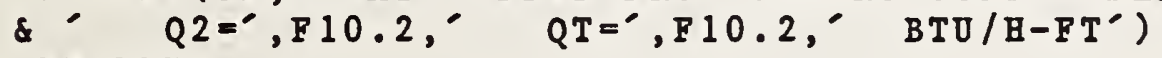

RETURN

END 


\begin{tabular}{|c|c|c|c|}
\hline $\begin{array}{l}\text { U.S. DEPT. OF COMM. } \\
\text { BIBLIOGRAPHIC DATA } \\
\text { SHEET (See instructions) }\end{array}$ & $\begin{array}{l}\text { 1. PUBLICATION OR } \\
\text { REPORT NO. } \\
86 / 3381\end{array}$ & 2. Performing Organ. Report Nof & $\begin{array}{r}\text { 3. Publication Date } \\
\text { MAY } 1986\end{array}$ \\
\hline \multicolumn{4}{|l|}{ 4. TITLE AND SUBTITLE } \\
\hline \multicolumn{4}{|c|}{$\begin{array}{l}\text { Minimum Life Cycle Cost Heat Losses for Shallow Trench } \\
\text { Underground Heat Distribution Systems }\end{array}$} \\
\hline \multicolumn{3}{|l|}{ 5. AUTHOR(S) } & \\
\hline \multicolumn{3}{|c|}{$\begin{array}{l}\text { 6. PERFORMING ORGANIZATION (If joint or other than NBS, see in structions) } \\
\text { NATIONAL BUREAU OF STANDARDS } \\
\text { DEPARTMENT OF COMMERCE } \\
\text { WASHINGTON, D.C. } 20234\end{array}$} & $\begin{array}{l}\text { 7. Contract/Grant No. } \\
\text { 8. Type of Report \& Period Covered }\end{array}$ \\
\hline \multicolumn{4}{|c|}{$\begin{array}{l}\text { 9. SPONSORING ORGANIZATION NAME AND COMPLETE ADDRESS (Street, City, Stote, Z1P) } \\
\text { Headquarters, U.S. Army Corps of Engineers, Washington, DC 20314-2300 } \\
\text { U.S. Navy, Naval Facilities Engineers Command, Alexandria, VA 22322-2300 } \\
\text { U.S. Air Force, Air Force Engineering and Services Center, Tyndall Air Force Base, } \\
\text { FL 32403-6001 }\end{array}$} \\
\hline
\end{tabular}

10. SUPPLEMENTARY NOTES

Document describes a computer program; SF-185, FIPS Software Summary, is attached.

11. ABSTRACT (A 200-word or less foctuol summory of most significont informotion. If document includes o signiflcant bibliogrophy or literoture survey. mention it here)

The rates of heat loss from two underground insulated pipes installed in a shallow trench were calculated using a computer program developed based on the application of the finite element method to solution of two-dimensional steady heat conduction problems. The calculated results of pipe heat loss under a specified groud temperature condition are summarized for a range of pipe insulation thickness, different sizes of shallow trench, and various pipe fluid temperatures. Methods of determining the minimum life-cycle cost heat loss and the corresponding economic insulation thickness for shallow trench heat distribution systems are presented. Life-cycle costing analysis was performed for two insulated pipes in a concrete trench to determine the cost of construction, annual energy cost associated with pipe heat loss, and yearly operating and maintenance costs. Based on this economic analysis, the least life-cycle cost heat loss and the optimum insulation thickness were determined for specified fluid temperatures in the heat supply and the return lines.

12. KEY WORDS (Six to twelve entries; alphabetical order; capitalize only proper names; and seporate key words by semicolons) finite element method; fuel energy cost; heat loss; life-cycle cost analys1s; shallow. trench; underground heat distribution system

13. AVAILABILITY

X] Unlimited

For Official Distribution. Do Not Release to NTIS

Order From Superintendent of Documents, U.S. Government Printing Office. Washington, D.C. 20402.

$x$ Order From National Technical Information Service (NTIS), Springfield, VA. 2216I
14. NO. OF PRINTED PAGES 45

15. Price $\$ 9.95$ 

